\title{
Photosynthetic pigments in 37 species (65 strains) of Haptophyta: implications for oceanography and chemotaxonomy
}

\author{
Manuel Zapata ${ }^{1}$, S. W. Jeffrey ${ }^{2, *}$, Simon W. Wright ${ }^{3}$, Francisco Rodríguez ${ }^{1}$, \\ José L. Garrido ${ }^{4}$, Lesley Clementson ${ }^{2}$ \\ ${ }^{1}$ Centro de Investigacións Mariñas (CIMA), Consellería de Pesca, Xunta de Galicia, Apartado 13, \\ 36620 Vilanova de Arousa, Spain \\ ${ }^{2}$ CSIRO Marine Research, GPO Box 1538, Hobart, Tasmania 7001, Australia \\ ${ }^{3}$ Australian Antarctic Division, Kingston, Tasmania 7050, Australia \\ ${ }^{4}$ Instituto de Investigacións Mariñas, Consejo Superior de Investigacións Cientificas (CSIC), \\ Eduardo Cabello 6, 36208 Vigo, Spain
}

\begin{abstract}
The pigment compositions of 37 species (65 strains) of cultured haptophytes were analysed using improved HPLC methods. We distinguished 8 pigment types based on the distribution of 9 chlorophyll $C(\mathrm{chl} c)$ pigments and 5 fucoxanthin derivatives. All types contained $\operatorname{chl} C_{2}$ and $\mathrm{Mg}$ 2,4-divinyl phaeoporphyrin $a_{5}$ monomethyl ester (MgDVP), fucoxanthin, diadinoxanthin and $\beta, \beta$ carotene. Pigment types were based on the following additional pigments: Type 1 : chl $c_{1}$; Type 2: chl $c_{1}$ and chl $C_{2}$-Pavlova gyrans-type; Type 3: chl $c_{1}$ and chl $c_{2}$-monogalactosyl diacylglyceride ester (chl $c_{2}$-MGDG [18:4/14:0]); Type 4: chl $c_{1}$, chl $c_{3}$ and non-polar chl $c_{1}$-like; Type 5: chl $c_{1}$, chl $c_{3}$, chl $c_{2}$ MGDG [18:4/14:0] and 4-keto-fucoxanthin; Type 6: chl $c_{3}$, monovinyl chl $c_{3}$ (MV-chl $c_{3}$ ), chl $c_{2}$-MGDG [18:4/14:0], 19'-hexanoyloxyfucoxanthin and its 4-keto derivative, and traces of 19'-butanoyloxyfucoxanthin; Type 7: similar to Type 6, minus MV-chl $c_{3}$ but with chl $c_{2}$-MGDG [14:0/14:0] added; Type 8: similar to Type 6, minus MV-chl $c_{3}$ but with significant 19'-butanoyloxyfucoxanthin. Taxonomic associations ranged from single genera to multiple families - Type 1: Pavlovaceae, Isochrysidaceae and Pleurochrysidaceae; Type 2: Pavlovaceae; Type 3: Isochrysidaceae; Type 4: Prymnesium spp.; Type 5: Ochrosphaera spp.; Type 6: Nöelaerhabdaceae, notably Emiliania spp.; Type 7: Chrysochromulina spp.; Type 8: Phaeocystaceae, Prymnesiaceae and Isochrysidaceae. These pigment types showed a strong correlation with available phylogenetic trees, supporting a genetic basis for the pigment associations. The additional marker pigments offer oceanographers greater power for detecting haptophytes in mixed populations, while also distinguishing a greater proportion of them from diatoms.
\end{abstract}

KEY WORDS: Haptophyta $\cdot$ HPLC $\cdot$ Chlorophylls $C \cdot$ Fucoxanthins $\cdot$ Pigment types $\cdot$ Phylogeny · Oceanography

Resale or republication not permitted without written consent of the publisher

\section{INTRODUCTION}

Haptophyte microalgae are an important component of the world's oceanic phytoplankton (Okada \& McIntyre 1977), blooming seasonally at polar, equatorial and subtropical latitudes (Brown \& Yoder 1994). The calcitecovered coccolithophorids such as Gephyrocapsa oceanica and Emiliania huxleyi dominate subtropical and sub-polar latitudes (Westbroek et al. 1994), and are significant globally in providing a long-term sink for inorganic carbon (Van der Wal et al. 1995, Paasche
2002). They also produce volatile dimethyl sulphide, which produces cloud-condensation nuclei, increasing cloud cover and affecting regional climates (Malin et al. 1994). In addition, some species (e.g. Chrysochromulina polylepis) are highly toxic to fin-fishes (Moestrup 1994). Monitoring of these and other phytoplankton groups is essential in order to follow seasonal successions, impacts of global warming on the marine environment, and harmful ecological events.

While taxonomic monitoring of the 200 known haptophyte species by microscopy is possible (Jordan et al. 
1995, Heimdal 1997), it is so time-consuming that oceanographers routinely use photosynthetic pigment profiles as chemotaxonomic markers of phytoplankton groups (Jeffrey et al. 1997b). In order to interpret pigment data from field samples, however, a thorough knowledge of the pigment composition of each of the likely species groups of the phytoplankton populations is necessary. Unfortunately very few wide-ranging pigment surveys of algal classes have been published, exceptions being for diatoms (Stauber \& Jeffrey 1988) and haptophytes (Jeffrey \& Wright 1994). Dominant species in field samples should always be assessed microscopically in representative samples (Andersen et al. 1996, Wright \& van den Enden 2000).

Knowledge of pigment characteristics of any group is always limited by the resolution of current separation methods. The haptophyte pigment study of Jeffrey \& Wright (1994), which used the SCOR-UNESCO HPLC method of Wright et al. (1991), distinguished most of the marker carotenoids, but failed to resolve monovinyl and divinyl analogues of chlorophyll $C$ (e.g. chlorophylls $C_{1}$ and $C_{2}$ ) and additional fucoxanthin derivatives such as 4keto-19'-hexanoyloxyfucoxanthin (Egeland et al. 2000). Nevertheless 4 useful pigment subgroups of the class were determined. New advances in HPLC pigment technology in the past decade (Jeffrey et al. 1999 [review], Zapata et al. 2000) have allowed a new examination of the pigment composition of this important group of microalgae in the present work.

The recent methods of Garrido \& Zapata (1997) and Zapata et al. (2000), in which polymeric $\mathrm{C}_{18}$ or monomeric $\mathrm{C}_{8}$ columns were used with pyridine as solvent modifier, have allowed separation of 11 chlorophyll $C$ pigments (including chlorophylls $C_{1}$ and $C_{2}$ ) across algal classes (Zapata et al. in press) and several new fucoxanthin derivatives. Structural determinations of 2 'nonpolar' chlorophyll $c$ pigments in Emiliania huxleyi and Chrysochromulina polylepis showed them to be, not phytylated chlorophyll $c$ derivatives (Nelson \& Wakeham 1989), but chlorophyll $C_{2}$-monogalactosyl diacylglycerol esters (Garrido et al. 2000, Zapata et al. 2001). The finding of a chlorophyll attached to a massive lipid side-chain is unique in the photosynthetic literature, and this advance may provide new clues to the photosynthetic mechanisms of these important marine species (Jeffrey \& Anderson 2000).

Van Lenning et al. (2003) recently used the Zapata et al. (2000) technique to study the pigment content of 9 species of Pavlovaceae, finding 3 pigment types that corresponded with phylogenetic relationships (based on $18 \mathrm{~S}$ rDNA) and morphological differences within the family.

In this paper, we re-examine the photosynthetic pigments of haptophyte cultures from 7 families (37 species; 65 strains) using the HPLC methods cited above.
Algal cultures were selected from 7 haptophyte families-Pavlovaceae, Phaeocystaceae, Prymnesiaceae, Isochrysidaceae, Noëlaerhabdaceae, Pleurochrysidaceae and Hymenomonadaceae - and included many globally important species. Multiple isolates of single species or genera from different geographic regions (e.g. Emiliania huxleyi, Phaeocystis antarctica and Chrysochromulina spp.) were also analysed to determine pigment variability. Of the 50 pigments separated, 9 chlorophyll $c$ pigments and 5 fucoxanthin derivatives were useful indicators of 8 haptophyte pigment types. This new information shows the diversity of chlorophyll $C$ and fucoxanthin pigments in the photosynthetic apparatus of haptophyte microalgae, and should provide useful additional biomarkers for haptophytes in field studies and new clues to photosynthetic mechanisms and phylogenetic relationships.

\section{MATERIALS AND METHODS}

Algal cultures. Haptophyte cultures (37 species, 65 strains) were obtained from 3 sources: the CSIRO Algal Culture Collection (Jeffrey \& LeRoi 1997, CSIRO 1998), the Australian Antarctic Division, and the ProvasoliGuillard National Centre for Culture of Marine Phytoplankton (CCMP). Strains, isolate information and culture conditions (media and growth temperatures) are listed in Table 1. Light irradiances were: 60 to $70 \mu \mathrm{mol}$ quanta $\mathrm{m}^{-2} \mathrm{~s}^{-1}$ on $12 \mathrm{~h}: 12 \mathrm{~h}$ light:dark cycles (CSIRO 42 strains, CCMP 14 strains) and $40 \mu \mathrm{mol}$ quanta $\mathrm{m}^{-2} \mathrm{~s}^{-1}$ on 16:8 h light:dark cycles (Australian Antarctic Division, 10 strains of Phaeocystis antarctica).

Sample preparation. Cultures were examined by light microscopy before HPLC pigment analysis to ensure the cells were in excellent health and morphology. Cells were harvested 4 to $6 \mathrm{~h}$ into the light cycle from cultures in exponential growth phase. We filtered $10 \mathrm{ml}$ of each culture onto $25 \mathrm{~mm}$ Whatman GF/F filters using less than $20 \mathrm{kPa}$ vacuum. Filters were frozen immediately at $-25^{\circ} \mathrm{C}$, and analysed within $12 \mathrm{~h}$.

Pigment extraction. Frozen filters were extracted under low light in Teflon-lined screw capped tubes with $5 \mathrm{ml} 95 \%$ methanol using a stainless steel spatula for filter-grinding. The tubes were chilled in a beaker of ice and sonicated for $5 \mathrm{~min}$ in an Ultrasonics Australia bath. Extracts were then filtered through $25 \mathrm{~mm}$ diameter hydrophilic Teflon (PTFE) syringe filters (MFS HP020, $0.2 \mu \mathrm{m}$ pore size) to remove cell and filter debris. An aliquot $(0.5 \mathrm{ml})$ of the methanol extract was mixed with $0.2 \mathrm{ml}$ of water and $200 \mu \mathrm{l}$ was injected immediately into the HPLC. This procedure avoids peak distortion of early eluting peaks (Zapata \& Garrido 1991) and prevents the loss of non-polar pigments prior to injection. 
Table 1. Haptophyte species, strain codes, culture media and growth temperatures of 37 species (65 strains) examined. CS = CSIRO Culture Collection of Living Microalgae, Hobart, Australia; CCMP = Provasoli-Guillard National Center for Culture of Marine Phytoplankton, USA. Culture medium: f/2 and variations fE/2, f/2-Si (Guillard \& Ryther 1962, Guillard 1975); G medium and dilutions G/2, GP5; GSe = G + selenium; GSe/2 (CSIRO modifications of GPM medium, Loeblich 1975); K= Keller medium (Keller et al. 1987; modified by CSIRO Algal Culture Group); L1, L2, L2* = L2 in diluted seawater (Guillard \& Hargraves 1993)

\begin{tabular}{|c|c|c|c|c|c|}
\hline Taxon & $\begin{array}{l}\text { Strain } \\
\text { code }\end{array}$ & $\begin{array}{l}\text { Culture } \\
\text { medium }\end{array}$ & $\begin{array}{l}\text { Growth } \\
\text { temp }\left({ }^{\circ} \mathrm{C}\right)\end{array}$ & $\begin{array}{l}\text { Geographic } \\
\text { origin }\end{array}$ & $\begin{array}{l}\text { Original designation } \\
\text { or synonym }\end{array}$ \\
\hline \multicolumn{6}{|l|}{ CLASS PAVLOVOPHYCEAE } \\
\hline \multicolumn{6}{|l|}{ Order Pavlovales } \\
\hline \multicolumn{6}{|l|}{ Family Pavlovaceae } \\
\hline Diacronema vlkianum Prauser & CS-266 & GSe & 17.5 & Ryde, Isle of Wight, UK & Plymouth 244, CCAP914/1 \\
\hline Diacronema sp. & CCMP1610 & L2* & 15 & Chesapeake Bay, USA & \\
\hline \multirow[t]{2}{*}{ Pavlova gyrans Butcher } & CCMP608 & L2 & 17 & Helfard, Cornwall, UK & MPPAV, Plymouth 93 \\
\hline & CS-213 & $\mathrm{f} / 2$ & 17.5 & Helfard, Cornwall, UK & Plymouth 93, CCMP608 \\
\hline \multirow[t]{2}{*}{ Pavlova lutheri (Droop) Green } & CS-23 & $f / 2$ & 17.5 & Halifax, Canada & \\
\hline & CS-182 & $f / 2$ & 17.5 & Finland & CCMP1325, MONO \\
\hline \multirow[t]{2}{*}{ Pavlova pinguis Green } & CS-286 & GSe & 17.5 & Madeira, Atlantic Ocean & Plymouth 471, CCAP 940/2 \\
\hline & CS-375 & GSe & 15 & Pipeclay Lagoon, Tasmania, Australia & PRPL01 \\
\hline \multirow[t]{2}{*}{ Pavlova sp. } & CS-50 & $\mathrm{f} / 2$ & 17.5 & Sargasso Sea & Woods Hole Tr.fl, CCMP613 \\
\hline & CS-63 & $f / 2$ & 17.5 & Port Phillip Bay, Victoria, Australia & SPECK 16.3 \\
\hline $\begin{array}{l}\text { Rebecca (Pavlova) salina } \\
\text { (Carter) Green }\end{array}$ & CS-49 & $\mathrm{f} / 2$ & 17.5 & Sargasso Sea & Woods Hole S1, CCMP1233 \\
\hline \multicolumn{6}{|l|}{ CLASS PRYMNESIOPHYCEAE } \\
\hline \multicolumn{6}{|l|}{ Order Phaeocystales } \\
\hline \multicolumn{6}{|l|}{ Family Phaeocystaceae } \\
\hline \multirow[t]{10}{*}{ Phaeocystis antarctica Karsten } & A $1-3$ & GP5 & 3 & Antarctica $\left(63^{\circ} 11^{\prime} \mathrm{S}, 85^{\circ} 43^{\prime} \mathrm{E}\right)$ & \\
\hline & A $1-4$ & GP5 & 3 & Antarctica $\left(68^{\circ} 47^{\prime} \mathrm{S}, 73^{\circ} 30^{\prime} \mathrm{E}\right)$ & \\
\hline & DE 10 & GP5 & 3 & Davis, Antarctica & \\
\hline & DE 12.1 & GP5 & 3 & Davis, Antarctica & \\
\hline & MSIA-1 & GP5 & 3 & Ice, Prydz Bay, Antarctica & \\
\hline & MSIA-2 & GP5 & 3 & Ice, Prydz Bay, Antarctica & \\
\hline & RG 1.2 & GP5 & 3 & Davis, Antarctica & \\
\hline & RG 2.2 & GP5 & 3 & Davis, Antarctica & \\
\hline & Т 4.1 & GP5 & 3 & Antarctica $\left(68^{\circ} 39^{\prime} \mathrm{S}, 72^{\circ} 21^{\prime} \mathrm{E}\right)$ & \\
\hline & Т 9.1 & GP5 & 3 & Antarctica $\left(68^{\circ} 39^{\prime} \mathrm{S}, 72^{\circ} 21^{\prime} \mathrm{E}\right)$ & \\
\hline $\begin{array}{l}\text { Phaeocystis cf. pouchetii } \\
\text { (Hariot) Lagerheim }\end{array}$ & CS-165 & GSe & 17.5 & Port Hacking NSW, Australia & \\
\hline Phaeocystis globosa Scherffel & CCMP627 & L2 & 17 & Gulf of Mexico & 1209 \\
\hline \multicolumn{6}{|l|}{ Order Prymnesiales } \\
\hline \multicolumn{6}{|l|}{ Family Prymnesiaceae } \\
\hline $\begin{array}{l}\text { Chrysochromulina camella } \\
\text { Leadbeater \& Manton }\end{array}$ & CS-268 & GSe & 15 & $49^{\circ} 10^{\prime} \mathrm{N}, 6^{\circ} 10^{\prime} \mathrm{W}$ & Plymouth 297 \\
\hline $\begin{array}{l}\text { Chrysochromulina ericina } \\
\text { (Parke) Manton }\end{array}$ & $\begin{array}{l}\text { CCMP282 } \\
\text { CCMP283 }\end{array}$ & $\begin{array}{l}\text { L1 } \\
\text { L1 }\end{array}$ & $\begin{array}{l}17 \\
24\end{array}$ & $\begin{array}{l}\text { Gulf of Maine, USA } \\
\text { Gulf of Maine, USA }\end{array}$ & $\begin{array}{l}8610 \mathrm{C} 3 \\
8610 \mathrm{G}\end{array}$ \\
\hline Chrysochromulina hirta Manton & CS-228 & GSe & 15 & - & Polar Institute Japan \\
\hline $\begin{array}{l}\text { Chrysochromulina kappa } \\
\text { Parke \& Manton }\end{array}$ & CCMP288 & L1 & 17 & $\begin{array}{l}\text { Bigelow Laboratory, } \\
\text { West Boothbay Harbor, USA }\end{array}$ & $3 \mathrm{D}$ \\
\hline $\begin{array}{l}\text { Chrysochromulina polylepis } \\
\text { Manton \& Parke }\end{array}$ & CCMP286 & L2 & 17 & Kristineberg, Sweden & ED2 \\
\hline $\begin{array}{l}\text { Chrysochromulina strobilus } \\
\text { Parke \& Manton }\end{array}$ & CS-231 & GSe & 15 & - & Polar Institute Japan \\
\hline Chrysochromulina sp. & CS-410 & GSe & 17.5 & Pipeclay Lagoon, Tasmania, Australia & \\
\hline \multirow[t]{2}{*}{ Imantonia rotunda Reynolds } & CCMP457 & L2 & 15 & $38^{\circ} 42^{\prime} \mathrm{N}, 72^{\circ} 22^{\prime} \mathrm{W}$ & IID2 \\
\hline & CS-194 & $\mathrm{fE} / 2$ & 17.5 & Gulf of Mexico & CCMP456 \\
\hline Prymnesium parvum Carter & CCMP708 & L2 & 15 & & PRYM \\
\hline $\begin{array}{l}\text { Prymnesium patelliferum } \\
\text { (Green, Hibberd \& Pienaar) }\end{array}$ & CS-345 & GSe & 17.5 & Cawthron Institute, New Zealand & CAWP 12 \\
\hline \multirow[t]{2}{*}{ Prymnesium patelliferum } & CS-288 & GSe & 17.5 & Dorset, UK & Plymouth 527, CCMP709 \\
\hline & CS-376 & GSe & 15 & Pipeclay Lagoon, Tasmania, Australia & \\
\hline Prymnesium sp. ${ }^{\text {a }}$ & CS-458 & GSe & 17.5 & Serpentine River, Western Australia & \\
\hline
\end{tabular}


Table 1 (continued)

\begin{tabular}{|c|c|c|c|c|c|}
\hline Taxon & $\begin{array}{l}\text { Strain } \\
\text { code }\end{array}$ & $\begin{array}{l}\text { Culture } \\
\text { medium }\end{array}$ & $\begin{array}{l}\text { Growth } \\
\text { temp }\left({ }^{\circ} \mathrm{C}\right)\end{array}$ & $\begin{array}{l}\text { Geographic } \\
\text { origin }\end{array}$ & $\begin{array}{l}\text { Original designation } \\
\text { or synonym }\end{array}$ \\
\hline \multicolumn{6}{|l|}{ Order Isochrysidales } \\
\hline \multicolumn{6}{|l|}{ Family Isochrysidaceae } \\
\hline $\begin{array}{l}\text { Chrysotila lamellosa } \\
\text { Anand emend. Green \& Parke }\end{array}$ & CS-272 & GSe & 17.5 & UK & Plymouth 408, CCAP 918/1 \\
\hline $\begin{array}{l}\text { Cricosphaera carterae } \\
\text { (Braarud \& Fagerland) Braarud }^{\text {b }}\end{array}$ & $\mathrm{CS}-40$ & $\mathrm{G}$ & 17.5 & - & F.T. Haxo Cr. cart. \\
\hline \multirow[t]{5}{*}{ Dicrateria inornata Parke } & CCMP355 & L2 & 15 & - & DICRAT \\
\hline & CS-254 & $\mathrm{f} / 2-\mathrm{Si}$ & 17.5 & - & CCMP355 \\
\hline & $\mathrm{CS}-267^{\mathrm{C}}$ & GSe & 17.5 & Plymouth, UK & Plymouth B, CCAP 915/1 \\
\hline & CCMP1323 & L2 & 15 & Isle of Man, UK & Plymouth I, CCAP 927/1 \\
\hline & CS-22 & $f / 2$ & 17.5 & Halifax, Canada & \\
\hline Isochrysis sp. & CS-177 & $f / 2$ & 17.5 & Tahiti, Society Islands & CCMP1324, T-ISO \\
\hline Pseudoisochrysis paradoxa Ott & CS-186 & $f / 2$ & 17.5 & York River, Virginia, USA & CCMP715, VA12 \\
\hline \multicolumn{6}{|l|}{ Family Noëlaerhabdaceae } \\
\hline $\begin{array}{l}\text { Emiliania huxleyi } \\
\text { (Lohmann) Hay \& Mohler }\end{array}$ & CCMP370 & L2 & 15 & Oslo fjord, Norway & $451 \mathrm{~B}$ \\
\hline \multirow[t]{10}{*}{ Emiliania huxleyi } & CCMP373 & L2 & 15 & Sargasso Sea & BT-6 \\
\hline & CS-57 & $\mathrm{f} / 2$ & 17.5 & Sargasso Sea & BT-6 \\
\hline & CS-275-2 & GSe & 15 & $60^{\circ} \mathrm{N} 20^{\circ} \mathrm{W}$, Iceland Basin & Plymouth G1779Ga \\
\hline & CS-279 & GSe & 15 & $24^{\circ} 27^{\prime} \mathrm{N}, 20^{\circ} 24^{\prime} \mathrm{W}$ & Plymouth DNN53/74/6 \\
\hline & CS-282 & GSe & 15 & $32^{\circ} \mathrm{N} 62^{\circ} \mathrm{W}$, Sargasso Sea & Plymouth M181 \\
\hline & CS-283 & GSe & 15 & Durban, South Africa & Plymouth M186 \\
\hline & CS-284 & GSe & 15 & Sargasso Sea & Plymouth MCH-1,CCMP375 \\
\hline & CS-363 & $\mathrm{G} / 2$ & 15 & Pipeclay Lagoon, Tasmania & \\
\hline & CS-369 & $\mathrm{K}$ & 15 & Pipeclay Lagoon, Tasmania & \\
\hline & CS-370 & $\mathrm{K}$ & 15 & Pipeclay Lagoon, Tasmania & \\
\hline Gephyrocapsa oceanica Kamptner & CS-335 & GSe/2 & 17.5 & Jervis Bay, NSW, Australia & \\
\hline \multicolumn{6}{|l|}{ Order Coccolithales } \\
\hline \multicolumn{6}{|l|}{ Family Pleurochrysidaceae } \\
\hline $\begin{array}{l}\text { Pleurochrysis aff. carterae } \\
\text { (Braarud \& Fagerland) Christiansen }\end{array}$ & CS-287 & GSe & 17.5 & Port Erin, Isle of Man, UK & $\begin{array}{l}\text { Plymouth 156, CCMP646 } \\
\text { CCAP 961/5 }\end{array}$ \\
\hline $\begin{array}{l}\text { Pleurochrysis roscoffensis } \\
\text { Chadfaud \& Feldman }\end{array}$ & CCMP1588 & L2 & 15 & Narragansett Bay, USA & CO791C \\
\hline \multicolumn{6}{|l|}{ Family Hymenomonadaceae } \\
\hline Ochrosphaera neapolitana Schussnig & CS-285 & GSe & 17.5 & Salcombe, UK & Plymouth 162, CCAP 923/1 \\
\hline Ochrosphaera verrucosa Schussnig & CCMP594 & L2 & 15 & Puerto Penasco, Mexico & UW 390, Norris 20-6-11 \\
\hline \multicolumn{6}{|l|}{ UNKNOWN } \\
\hline \multirow[t]{2}{*}{ Haptophyte (unidentified) } & CS-124 & $\mathrm{G} / 2$ & 25 & \\
\hline & CS-260 & $\mathrm{fE} / 2$ & 25 & & Dunk Island, Queensland, Australia \\
\hline
\end{tabular}

HPLC pigment analyses. We used 2 HPLC methods: the $\mathrm{C}_{8}$ method of Zapata et al. (2000), which was used for all haptophyte cultures, and the $\mathrm{C}_{18}$ method of Garrido \& Zapata (1997), which was used for a subset of the cultures. The chromatographic equipment for the $\mathrm{C}_{8}$ method was a Waters 600 pump and a Waters 996 diode-array detector (samples analysed at CSIRO Marine Research, Hobart, Australia). The stationary phase was a $\mathrm{C}_{8}$ column (Waters Symmetry, $150 \times$ $4.6 \mathrm{~mm}, 3.5 \mu \mathrm{m}$ particle size, $100 \AA$ pore size) thermostated at $25^{\circ} \mathrm{C}$ either by means of a column oven, or a $25^{\circ} \mathrm{C}$ circulating water bath. Mobile phases were: $\mathrm{A}=$ methanol:acetonitrile: aqueous pyridine solution ( $0.25 \mathrm{M}$ pyridine, $\mathrm{pH}$ adjusted to 5.0 with acetic acid) in the proportions 50:25:25 (v/v/v), and B = acetonitrile: acetone $(80: 20 \mathrm{v} / \mathrm{v})$. A segmented linear gradient was (time in $\min , \% \mathrm{~B}$ ): $0 \mathrm{~min}, 0 \%$; $18 \mathrm{~min}, 40 \%$; $22 \mathrm{~min}$, $100 \%$; $38 \mathrm{~min}, 100 \%$. Initial conditions were reestablished by reversed linear gradient (4 min). Flow rate was $1 \mathrm{ml} \mathrm{min}^{-1}$.

The $C_{18}$ HPLC method of Garrido \& Zapata (1997) was used to analyse 12 haptophyte species (14 strains) from 
CCMP, cultured at the Instituto de Investigacións Mariñas. The HPLC equipment in the Spanish laboratory was a Waters Alliance HPLC System with a 2690 separations module, a Waters 996 photodiode array detector (350 to $750 \mathrm{~nm} ; 1.2 \mathrm{~nm}$ optical resolution) interfaced to a Waters 474 scanning fluorometer (samples analysed at Centro de Investigacións Mariñas, Spain). The stationary phase was a polymeric $\mathrm{C}_{18}$ column (Vydac 201 TP54, $250 \times 4.6 \mathrm{~mm}, 5 \mu \mathrm{m}$ particle size, $300 \AA$ pore size) thermostated at $27^{\circ} \mathrm{C}$ by a column oven. Mobile phases were: $\mathrm{A}=$ methanol:acetonitrile:aqueous pyridine solution $(0.25 \mathrm{M}$ pyridine, $\mathrm{pH}$ adjusted to 5.0 with acetic acid) in the proportions 45:35:20 (v/v/v), and B = acetonitrile:acetone $(60: 40, \mathrm{v} / \mathrm{v})$. A segmented linear gradient was programmed as follows (time in $\min , \% \mathrm{~B}$ ): $0 \mathrm{~min}, 0 \%$; $28 \mathrm{~min}, 60 \%$; $32 \mathrm{~min}, 100 \%$; $38 \mathrm{~min}, 100 \%$. Initial conditions were re-established by reversed linear

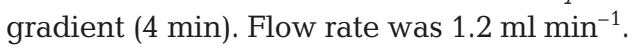

The 2 HPLC techniques achieve separations primarily by differences in hydrophobic interactions of the pigments with the stationary phase, and the polymeric $\mathrm{C}_{18}$ method has an additional shape-dependent mechanism that allows separation of pigments with very similar molecular structures (see Garrido \& Zapata 1997). Using both systems allowed comparison of unknown pigments with pigment standards under differing conditions (Bjørnland 1997, Jeffrey \& Mantoura 1997b).

Pigment identification. Pigments were identified either by co-chromatography with authentic standards obtained from SCOR (Scientific Commitee for Oceanic Research) reference cultures and diode-array spectroscopy (see Zapata et al. 2000) or by liquid chromatography - mass spectrometry. After checking for peak purity, spectral information was compared with a library of chlorophyll and carotenoid spectra from pigments prepared from standard phytoplankton cultures (SCOR cultures, see Jeffrey \& Wright 1997). For both known and novel compounds, electrospray mass spectra (ESMS) were obtained with a Thermo Quest-Finnigan Navigator mass spectrometer coupled to a Thermo Quest liquid chromatograph with a Waters Symmetry $C_{18}(150$ $\times 2 \mathrm{~mm}, 3.5 \mu \mathrm{m}$ particle size, $100 \AA$ pore size) column. Each pigment was injected using $95 \%$ aqueous methanol as mobile phase at a flow rate of $200 \mu \mathrm{min}^{-1}$. Mass spectra of carotenoids were acquired in positive ion mode (insert probe capillary voltage $=4 \mathrm{kV}$, probe temperature $=200^{\circ} \mathrm{C}$, cone voltage $=30 \mathrm{~V}$ ).

Pigment nomenclature and abbreviations were as suggested by SCOR Working Group 78 (Jeffrey \& Mantoura 1997a), noting that MgDVP is also known as divinyl-protochlorophyllide (DV-Pchlid) (Zapata et al. in press). For nonpolar chlorophyll $c$-like pigments whose molecular structures have recently been elucidated, the nomenclature was chl $C_{2}$-MGDG [18:4/14:0] for the major compound from Emiliania huxleyi (Garrido et al.
2000), and chl $c_{2}$-MGDG [14:0/14:0] for the major compound from Chrysochromulina polylepis (Zapata et al. 2001). Fatty acids in these chl $c$-MGDG pigments are designated as 'total number of $\mathrm{C}$ atoms:number of double bonds'. For chlorophylls whose molecular structure is unknown, the pigment name includes a reference to the most likely chl $c$ chromophore ( $\mathrm{chl} c_{1}, c_{2}$ and $c_{3}$-like), as well as the species in which the pigment was initially detected (e.g. chl $C_{2}$-like Pavlova gyrans-type, nonpolar chl $\mathrm{C}_{2}$-like Chrysochromulina hirta-type).

Pigment quantification. HPLC calibration by external standards was performed using chlorophyll and carotenoid standards isolated from microalgal cultures (Zapata et al. 2000). The molar extinction coefficients $\left(\varepsilon_{i}\right.$ $1 \mathrm{~mol}^{-1} \mathrm{~cm}^{-1}$ ) provided by Jeffrey (1997b) were used for pigment quantification. For chl $c$-like pigments whose molar extinction coefficients are not available (i.e. chl $c_{3}$, MV-Chl $C_{3}$, and chl $C_{2}$-like Pavlova gyrans-type) the mean of the extinction coefficients for chl $c_{1}$ and $c_{2}$ at the blue absorption band (see Jeffrey et al. 1997a) was used. The nonpolar chls $c$ were quantified by using the molar extinction coefficient of the appropriate $\operatorname{chl} C_{2}$ or chl $c_{1}$ chromophore. For fucoxanthin-related compounds (i.e. acyloxy and 4-keto derivatives), the molar extinction coefficient for fucoxanthin was used, following the recommendations of Jeffrey et al. (1997a), even though the absorption spectra of fucoxanthin-derivatives differ slightly from those of the parent compounds. Thus pigment to chl a ratios are expressed on a molar basis (mol $\left.\mathrm{mol}^{-1}\right)$.

\section{RESULTS}

\section{Chromatographic resolution and pigment identities}

The elution order of pigments by the Zapata et al. (2000) method is shown in Table 2 together with retention times and visible absorption maxima in eluent. Of the 44 pigments, 25 were well-known chlorophylls and carotenoids, and had previously been characterised (Jeffrey \& Wright 1987, Bjørnland \& Liaaen-Jensen 1989, Fookes \& Jeffrey 1989, Jeffrey 1989, Jeffrey et al. 1997b, Helfrich et al. 1999, Egeland et al. 2000, Zapata et al. 2000). Structures of chlorophyll c pigments may be found in Jeffrey (1997a) and Zapata et al. (in press), and structures of algal carotenoids in Bjørnland (1997) and Egeland et al. (2000). We also detected 7 unknown pigments with chlorophyll $c$-like spectra and 12 unknown pigments with carotenoid-like spectra in trace quantities. Pigments used to discriminate haptophyte pigment types (see next subsection) are given in boldface in Table 2.

One important unknown carotenoid isolated from Ochrosphaera verrucosa was tentatively identified as 4keto-fucoxanthin. Electrospray mass spectra (ES-MS) of 
Table 2. Elution and visible absorption characteristics of pigments in eluent from haptophyte cultures using $\mathrm{C}_{8}$ HPLC method (Zapata et al. 2000). Wavelengths in parentheses denote shoulders. Pigments in boldface are those used to discriminate pigment types

\begin{tabular}{|c|c|c|c|c|c|c|}
\hline \multirow{2}{*}{$\begin{array}{l}\text { Peak } \\
\text { no. } \\
\end{array}$} & \multirow{2}{*}{$\begin{array}{l}\text { Pigment } \\
\text { (Solvent front) }\end{array}$} & \multirow[t]{2}{*}{ Abbreviation } & \multirow{2}{*}{$\begin{array}{c}\begin{array}{c}\text { Time } \\
(\mathrm{min})\end{array} \\
1.93\end{array}$} & \multicolumn{3}{|c|}{$\lambda$ maxima in eluant $(\mathrm{nm})$} \\
\hline & & & & & & \\
\hline 1 & Chlorophyll $c_{3}$ & $\operatorname{chl} C_{3}$ & 7.19 & 459 & 591 & $(629)$ \\
\hline 2 & Chlorophyll $c_{2}$-like from Pavlova gyrans & chl $c_{2} P$. gyrans-type & 7.71 & 459 & 586 & 635 \\
\hline 3 & Monovinyl chlorophyll $c_{3}$ & $\mathrm{MV}$ chl $c_{3}$ & 7.87 & 452 & 586 & 631 \\
\hline 4 & Unknown chlorophyll $C$ & unk-chl $C$ & 9.20 & 450 & 583 & 631 \\
\hline 5 & Chlorophyllide $a$ & chlide $a$ & 10.46 & 430 & 581 & 663 \\
\hline 6 & Mg-2,4-divinyl phaeoporphyin $a_{5}$ monomethyl ester ${ }^{a}$ & MgDVP & 10.50 & 439 & 577 & 628 \\
\hline 7 & Chlorophyll $c_{2}$ & $\operatorname{chl~} C_{2}$ & 11.05 & 453 & 586 & 635 \\
\hline 8 & Chlorophyll $c_{1}$ & $\operatorname{chl} c_{1}$ & 11.74 & 449 & 583 & 633 \\
\hline 9 & Methyl-chlorophyllide $a$ & Me-chlide $a$ & 12.46 & 430 & 581 & 663 \\
\hline 10 & Unknown 19'-butanoyloxyfucoxanthin-like & unk-car 1 & 16.25 & & 448 & 472 \\
\hline 11 & 4-keto-fucoxanthin ${ }^{b}$ & 4 -k-fuco & 17.29 & & 453 & \\
\hline 12 & 19'-butanoyloxyfucoxanthin & but-fuco & 17.63 & & 447 & 471 \\
\hline 13 & Fucoxanthin & fuco & 18.27 & & 450 & \\
\hline 14 & Unknown fucoxanthin derivative & unk-car 2 & 19.15 & & 447 & 471 \\
\hline 15 & 4-keto-19'-hexanoyloxyfucoxanthin & 4-k-hex-fuco & 20.18 & & 448 & 472 \\
\hline 16 & Violaxanthin & violax & 20.30 & 417 & 441 & 471 \\
\hline 17 & 19'-hexanoyloxyfucoxanthin & hex-fuco & 20.91 & & 447 & 471 \\
\hline 18 & Unknown carotenoid $\lambda_{\max } 447$ & unk-car 3 & 21.85 & & 447 & 475 \\
\hline 19 & Diadinochrome & diadchr & 21.91 & $(406)$ & 429 & 457 \\
\hline 20 & Diadinoxanthin & diadino & 22.54 & $(422)$ & 448 & 477 \\
\hline 21 & cis-fucoxanthin & C-fuco & 23.31 & & 442 & \\
\hline 22 & Unknown carotenoid $\lambda_{\max } 448$ & unk-car 4 & 23.84 & & 448 & 471 \\
\hline 23 & Unknown carotenoid $\lambda_{\max } 447$ & unk-car 5 & 24.38 & & 447 & 470 \\
\hline 24 & Diatoxanthin & diato & 25.66 & $(426)$ & 454 & 482 \\
\hline 25 & $\begin{array}{l}\text { Non-polar chlorophyll } c_{2} \text {-like from } \\
\text { Chrysochromulina hirta }\end{array}$ & np-chl $c_{2} C$. hirta-type & 26.84 & 455 & 584 & 633 \\
\hline 26 & Unknown carotenoid $\lambda_{\max } 447$ & unk-car 6 & 26.95 & $(420)$ & 447 & 472 \\
\hline 27 & Unknown carotenoid $\lambda_{\max } 442$ & unk-car 7 & 28.00 & 418 & 442 & 471 \\
\hline 28 & Unknown carotenoid $\lambda_{\max } 445$ & unk-car 8 & 28.00 & $(419)$ & 445 & 471 \\
\hline 29 & Unknown carotenoid $\lambda_{\max } 446$ & unk-car 9 & 28.00 & $(419)$ & 446 & 473 \\
\hline 30 & Unknown carotenoid $\lambda_{\max } 448$ & unk-car 10 & 28.92 & 426 & 448 & 477 \\
\hline 31 & Non-polar chlorophyll $c_{2}$-like from Emiliania huxleyi & np-chl $c_{2}$ E. huxleyi-type & 30.09 & 454 & 584 & 631 \\
\hline 32 & Non-polar chlorophyll $c_{2}$-like from Emiliania huxleyi & np-chl $c_{2} E$. huxleyi-type & 30.39 & 454 & 584 & 631 \\
\hline 33 & Non-polar chlorophyll $c_{2}$-like from Emiliania huxleyi & np-chl $c_{2} E$. huxleyi-type & 30.62 & 454 & 584 & 631 \\
\hline 34 & $\begin{array}{l}\text { Chlorophyll } c_{2} \text { monogalactosyldiacylglyceride ester } \\
\text { from Emiliania huxleyi }\end{array}$ & chl $c_{2}$-MGDG [18:4/14:0] & 30.82 & 454 & 584 & 631 \\
\hline 35 & Non-polar chlorophyll $c_{1}$-like from Prymnesium parvum & np-chl $c_{1} P$. parvum-type & 31.08 & 451 & 579 & 632 \\
\hline 36 & Chlorophyll $a$ allomer & chl $a$ allomer & 31.27 & 430 & 615 & 662 \\
\hline 37 & Chlorophyll a & $\operatorname{chl} a$ & 31.48 & 431 & 617 & 662 \\
\hline 38 & $\begin{array}{l}\text { Chlorophyll } c_{2} \text { monogalactosyldiacylglyceride ester } \\
\text { from Chrysochromulina polylepis }\end{array}$ & $\operatorname{chl} c_{2}$-MGDG [14:0/14:0] & 31.83 & 454 & 584 & 631 \\
\hline 39 & Chlorophyll a epimer & $\operatorname{chl} a^{\prime}$ & 32.06 & 430 & 615 & 664 \\
\hline 40 & Phaeophytin $a$ & phytin a & 33.21 & 409 & 608 & 665 \\
\hline 41 & $\beta, \varepsilon$-carotene & $\beta \varepsilon$-car & 33.64 & $(422)$ & 448 & 476 \\
\hline 42 & $\beta, \beta$-carotene & $\beta \beta$-car & 33.80 & $(426)$ & 454 & 481 \\
\hline 43 & cis- $\beta, \beta$-carotene & c- $\beta \beta$-car & 34.11 & $(426)$ & 452 & 478 \\
\hline
\end{tabular}

the compound and that of fucoxanthin are shown in Fig. $1 \mathrm{~A}, \mathrm{~B}$ together with their visible absorption spectra (Fig. 1C,D). Fig. 1A presents the mass spectrum of fucoxanthin in positive-ion mode (molecular weight = 658.92) showing signals to the sodium derivative [M+ $\mathrm{Na}]^{+}=681.7$, and the protonated derivative $[\mathrm{M}+\mathrm{H}]^{+}=$
659.6 molecular ions, and major mass fragments at $641=$ $[\mathrm{M}+\mathrm{H}-18]^{+}$and $581=[\mathrm{M}+\mathrm{H}-18-60]^{+}$. In comparison, the unknown fucoxanthin derivative (Fig. 1B) was $14 \mathrm{U}$ heavier, $695=[\mathrm{M}+\mathrm{Na}]^{+} ; 673=[\mathrm{M}+\mathrm{H}]^{+} ; 655=[\mathrm{M}+$ $\mathrm{H}-18]^{+} ; 595=[\mathrm{M}+\mathrm{H}-18-60]^{+}$, suggesting that the unknown derivative is a ketofuco-xanthin. Visible absorp- 

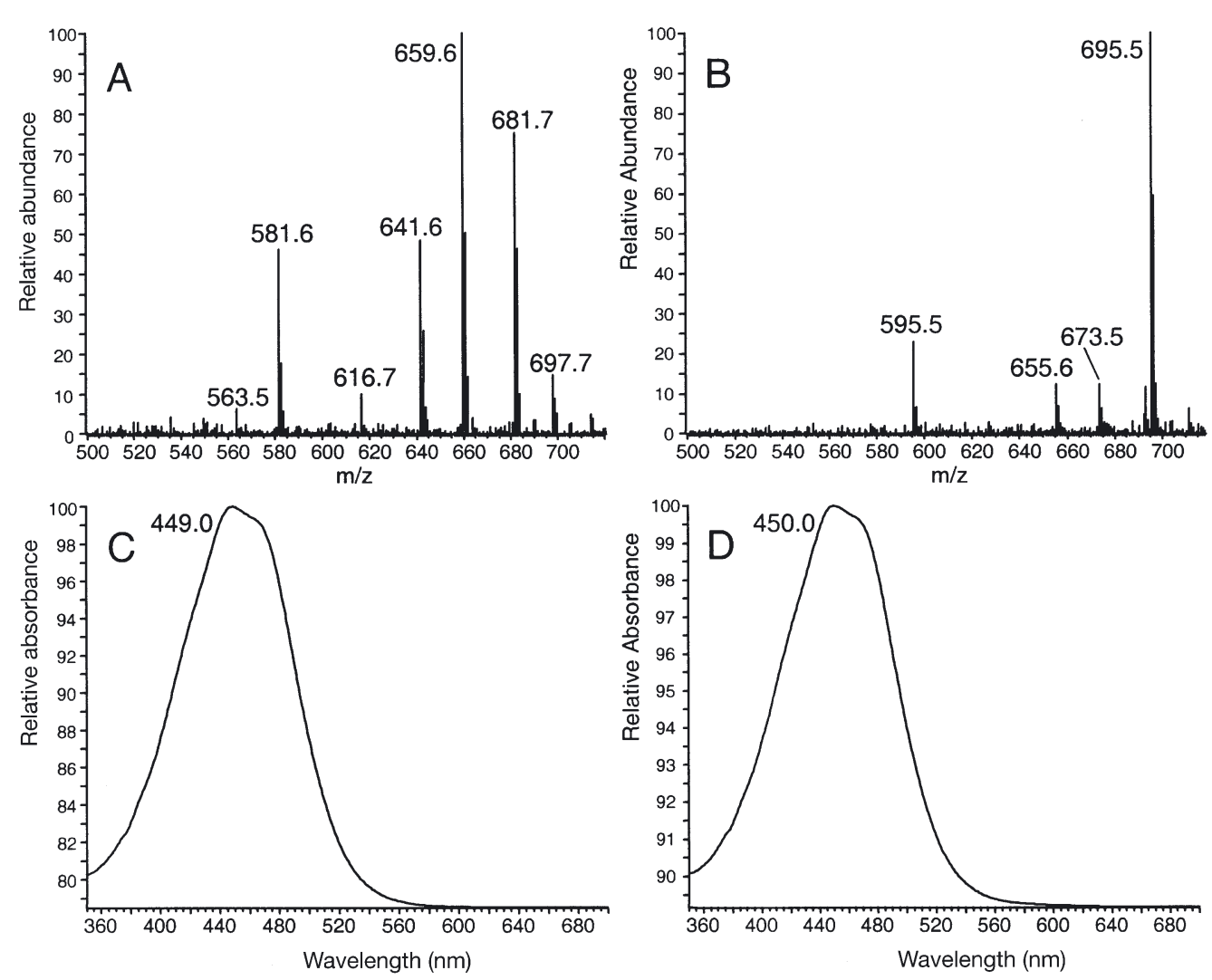

Fig. 1. Mass spectra (A, B) and visible spectra (C, D) of fucoxanthin and an unknown carotenoid (tentatively identified as 4-ketofucoxanthin) isolated from Ochrosphaera verrucosa. Mass spectra were obtained by electrospray mass spectrometry in positive-ion mode

tion spectra of the 2 compounds (Fig. 1C,D) showed that the unknown derivative was indistinguishable from fucoxanthin, except for a $1 \mathrm{~nm}$ bathychromic shift of the wavelength of maximum absorption, suggesting the keto group does not affect the chromophore. The position C-4 for the keto substituent is suggested by analogy with the keto derivative of 19'-hexanoyloxyfucoxanthin (Egeland et al. 2000). Further confirmation of this tentative structure by NMR (nuclear magnetic resonance) techniques is needed.

Fig. 2 shows representative chromatograms from each of the 8 haptophyte pigment types found using the $\mathrm{C}_{8}$ HPLC method. The polar $\mathrm{chl} c$ pigments eluted before the fucoxanthin derivatives while the non-polar chl $C$ pigments eluted near chl a. Fig. 3 shows 4 selected haptophyte species separated by the polymeric $\mathrm{C}_{18}$ method of Garrido \& Zapata (1997). Using this method, fucoxanthin derivatives preceded the polar chl $c$ pigments whereas the non-polar chl $C_{2}$-MGDG derivatives eluted after chlorophyll $a$ in the hydrophobic region of the chromatogram. The different pigment resolution of these methods allowed additional confirmation of peak identities.

\section{Haptophyte pigment composition and definition of pigment types}

Quantitative data for all strains are shown as molar pigment to chl a ratios, grouped together in similar pigment types, Type 1 being the most simple and Type 8 the most complex (Table 3). Chl $c$ distribution patterns across haptophyte families and those of the fucoxanthin derivatives are summarised separately in Tables $4 \& 5$, respectively. Pigment types were allocated on the basis of increasing diversity of chl $c$ and fucoxanthin pigments, noting that chl $c_{2}$, MgDVP, fucoxanthin, diadinoxanthin and $\beta, \beta-$ carotene were common to all pigment types.

Table 4 shows that MgDVP and chl $c_{2}$ were present in all pigment types and were accompanied by $\mathrm{chl} c_{1}$ (Types 1 to 5); chl $c_{3}$ (Types 4 to 8); chl $c_{2}$-MGDG [18:4/ 14:0] (Types 3 to 8); with each of the remaining $4 \mathrm{chl} c$ pigments found in only 1 pigment type i.e. chl $C_{2}$-like Pavlova gyrans-type (Type 2); MV-chl $c_{3}$ (Type 6); non-polar chl $c_{1}$-like pigment (Type 4) and chl $c_{2}$-MGDG [14:0/14:0] (Type 7).

Table 5 shows that fucoxanthin occurred in all pigment types and was present as the only fucoxanthin pigment in Types 1 to 4 . It was accompanied by 
4-keto-fucoxanthin in Type 5; with 19'-hexanoyloxyfucoxanthin, 4-keto-hexanoyloxyfucoxanthin and traces of 19'-butanoyloxyfucoxanthin in Types 6 and 7; and with significant quantities of 19'-butanoyloxyfucoxanthin, co-dominant with 19'-hexanoyloxyfucoxanthin and 4-keto-hexanoyloxyfucoxanthin, in Type 8.
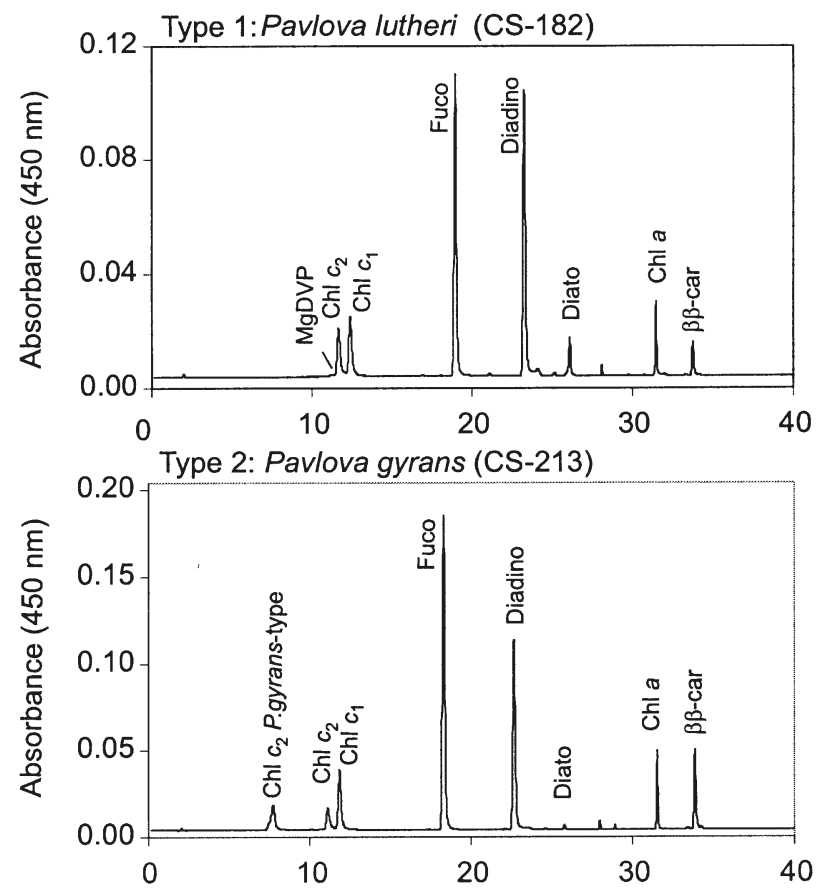

Type 3: Isochrysis galbana (CS-22)

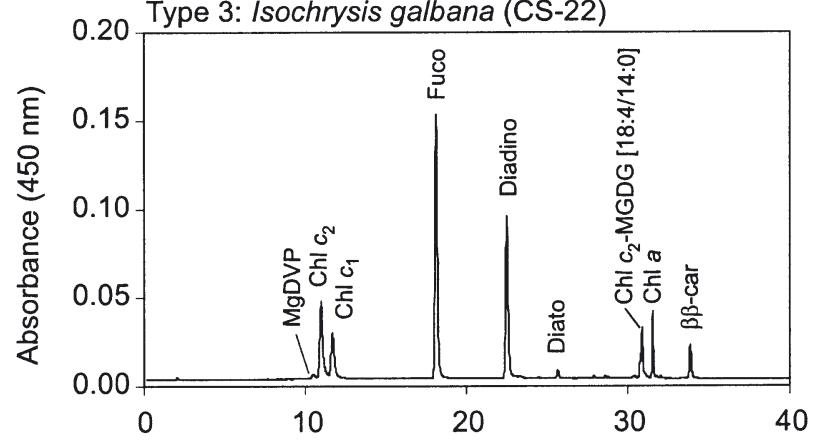

Type 4: Prymnesium parvum (CS-345)

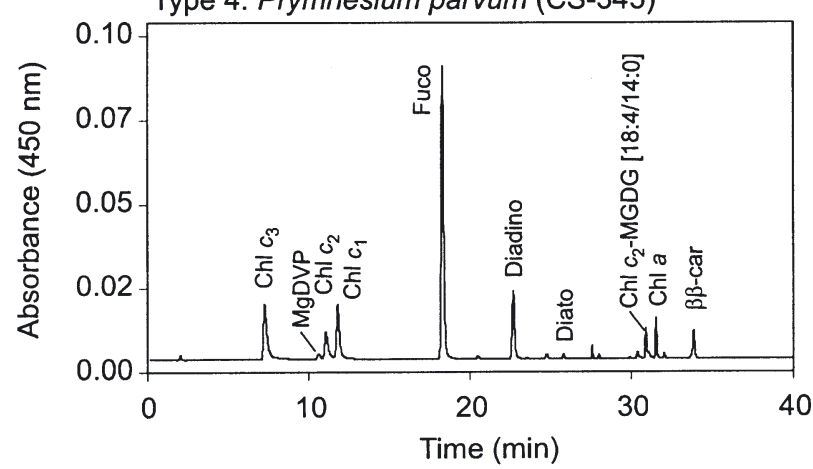

\section{Quantitative pigment data}

Quantitative abundances of chl $c$ and fucoxanthin pigments derived from data in Table 3 are shown as molar percentages of total $\mathrm{chl} c$ and total fucoxanthin in Tables 6 \& 7 .
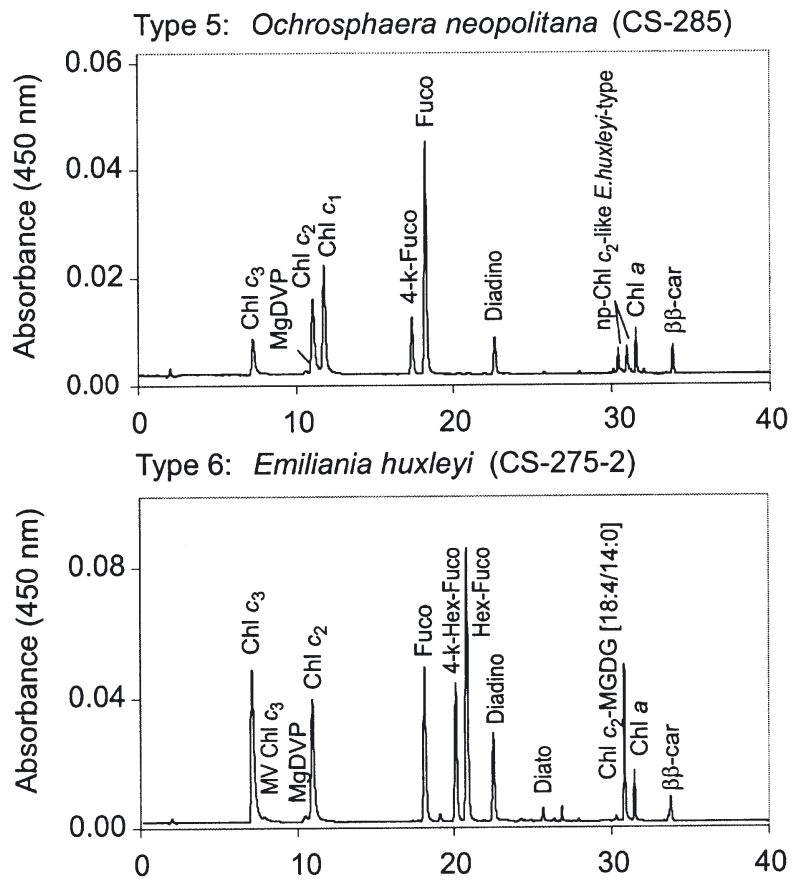

Type 7: Chrysochromulina camella (CS-268)
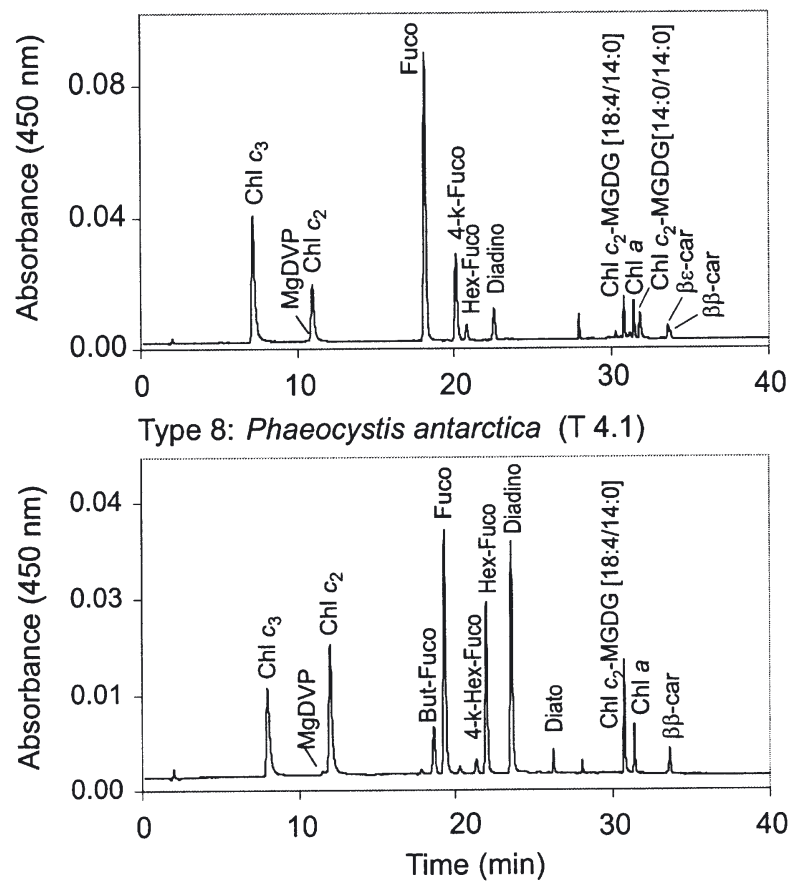

Fig. 2. HPLC chromatograms $\left(\mathrm{C}_{8}\right.$ method) of haptophyte species representing each pigment type. Detection by absorbance at $450 \mathrm{~nm}$. Peak identifications as in Table 2 

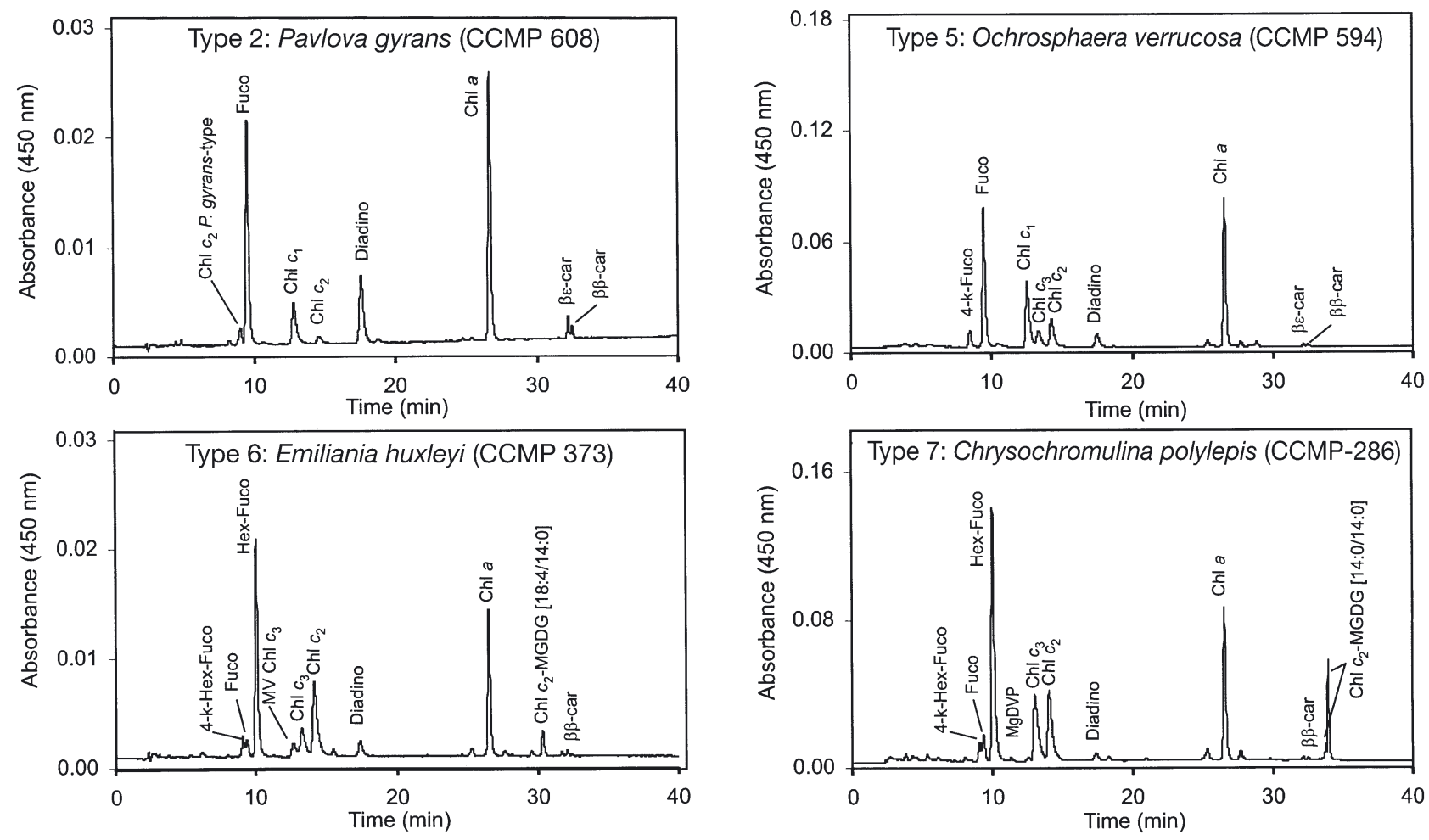

Fig. 3. HPLC chromatograms (polymeric $\mathrm{C}_{18}$ method) of haptophyte species belonging to selected pigment types. Detection by absorbance at $450 \mathrm{~nm}$. Peak identifications as in Table 2

Chlorophyll $\boldsymbol{c}$ pigments. The $9 \mathrm{chl}$ c pigments (quantified as molar percentages of total chlorophyll $C$ ) ranged from major to trace across the species. Chl $C_{1}, C_{2}$ and $C_{3}$ were always of major importance, each ranging from one-third to one-half of the total chl $C$ (Table 6). Chl $C_{2}$ occurred in all haptophyte pigment Types (1 to 8), while chl $c_{1}$ occurred in pigment Types 1 to 5 and chl $c_{3}$ in Types 4 to 8 . Chl $c_{1}$ and $c_{3}$ cooccurred in haptophyte pigment Types 4 and 5. The chl $C_{2}$-like Pavlova gyrans-type pigment was also of major significance, and reached 22 to $36 \%$ of the total chlorophyll $C$ in haptophyte pigment Type 2. The newly discovered minor pigment chl $C_{2}$-MGDG [18:4/14:0] reached 6 to $15 \%$ of the total chl $C$ in pigment Types 3 to 8 , while the remaining 3 pigments, MV-Chl $c_{3}$, chl $c_{2}$-MGDG [14:0/14:0] and MgDVP, occurred only in trace quantities at 1 to $5 \%$ of the total chl $C_{\text {, }}$ in pigment Types 6,7 and 1 to 8, respectively.

Fucoxanthin derivatives. Variations in relative abundance of the 5 fucoxanthin derivatives across haptophyte species were less dramatic than those of chl $C$, but they were no less significant (Table 7 ). Fucoxanthin was always abundant in all strains and was the only fucoxanthin derivative in haptophyte pigment Types 1 to 4 . In pigment Type 5, fucoxanthin co-occurred with the minor pigment 4-keto- fucoxanthin which represented 7 to $20 \%$ of the total fucoxanthins.

19'-hexanoyloxyfucoxanthin almost always assumed dominance of, or co-dominance with, fucoxanthin when acyloxyfucoxanthins were present (pigment Types 6 to 8). The 4-keto derivative of 19'-hexanoyloxyfucoxanthin usually co-occurred with its parent compound as a minor pigment, representing 7.5 to $22.7 \%$ of the total fucoxanthins (Types 6 to 8). Finally, 19'-butanoyloxyfucoxanthin, present only in traces $(0.2$ to $1.1 \%)$ in haptophyte pigment Types 6 and 7 , generally assumed major importance (up to $30 \%$ ) in most strains belonging to haptophyte pigment Type 8 (e.g. Phaeocystis spp.).

Fig. 4 shows that a significant relationship $(p<0.05)$ existed between the total fucoxanthins and the total chl $c$ pigments, normalised to chl $a$. The implication of these observations is unknown, but may indicate a stoichiometric relationship between chl $C$ pigments and fucoxanthin derivatives in the light-harvesting complexes of the Haptophyta.

Detailed examination of Table 3 shows several exceptions to these generalizations-mainly some pigment absences which may represent concentrations below detection limits (e.g. MgDVP in haptophyte pigment Types 1, 2, 3, 6, 7 and 8). 
Table 3. Pigment:chlorophyll (chl) a molar ratios of 37 species (65 strains) of haptophyte cultures. : below detection limits; $P$. gyr : Pavlova gyrans; chl $C_{2}$-MGDG [18/14], [14/14]: chl $C_{2}$-monogalactosyl diacylglyceride ester [18:4/14:0], [14:0/14:0], respectively. Other abbreviations as in Table 2

\begin{tabular}{|c|c|c|c|c|c|c|c|c|c|c|c|c|c|}
\hline $\begin{array}{l}\text { Pignent type } \\
\text { Species }\end{array}$ & $\begin{array}{l}\text { Strain } \\
\text { code }\end{array}$ & $\operatorname{chl} C_{3}$ & $\begin{array}{c}\text { chl } c_{2} \\
P . g y r \\
\text { type }\end{array}$ & $\begin{array}{l}\text { MV- } \\
\text { chl } c_{3}\end{array}$ & MgDVP & $\operatorname{chl} C_{2}$ & $\operatorname{chl} C_{1}$ & $\begin{array}{l}\mathrm{chl} c_{2}^{-} \\
\text {MGDG } \\
{[18 / 14]}\end{array}$ & $\begin{array}{l}\text { chl } C_{2}^{-} \\
\text {MGDG } \\
{[14 / 14]}\end{array}$ & $\begin{array}{l}\text { but- } \\
\text { fuco }\end{array}$ & fuco & $\begin{array}{l}\text { 4-k- } \\
\text { hex- } \\
\text { fuco }\end{array}$ & $\begin{array}{l}\text { Hex } \\
\text { fuco }\end{array}$ \\
\hline \multicolumn{14}{|l|}{ Type 1} \\
\hline Chrysotila lamellosa & $\mathrm{CS}-272$ & - & - & - & 0.003 & 0.039 & 0.034 & - & - & - & 0.282 & - & - \\
\hline Diacronema vlkianum & CS-266 & _- & _- & _- & - & 0.034 & 0.053 & _- & _- & _- & 0.312 & _- & _- \\
\hline Diacronema sp. & CCMP 1610 & - & - & - & 0.004 & 0.039 & 0.072 & - & - & - & 0.249 & - & - \\
\hline \multirow[t]{2}{*}{ Pavlova lutheri } & CS-23 & - & - & - & - & 0.036 & 0.036 & - & - & - & 0.266 & - & - \\
\hline & CS-182 & - & - & - & 0.001 & 0.042 & 0.048 & - & - & - & 0.317 & - & - \\
\hline Pleurochrysis roscoffensis & CCMP 1588 & - & - & - & 0.007 & 0.051 & 0.071 & - & - & - & 0.259 & - & - \\
\hline Pleurochrysis aff. carterae & CS-287 & - & - & - & 0.002 & 0.037 & 0.065 & - & - & - & 0.320 & - & - \\
\hline \multicolumn{14}{|l|}{ Type 2} \\
\hline \multirow[t]{2}{*}{ Pavlova gyrans } & CCMP 608 & - & 0.033 & - & 0.004 & 0.016 & 0.078 & - & - & - & 0.288 & - & - \\
\hline & CS-213 & - & 0.025 & - & 0.001 & 0.018 & 0.045 & - & - & - & 0.316 & - & - \\
\hline \multirow[t]{2}{*}{ Pavlova pinguis } & CS-286 & - & 0.032 & - & 0.001 & 0.023 & 0.059 & - & - & - & 0.429 & - & - \\
\hline & CS-375 & - & 0.053 & - & - & 0.022 & 0.077 & - & - & - & 0.503 & - & - \\
\hline Pavlova sp. & CS-50 & - & 0.028 & - & - & 0.017 & 0.060 & - & - & - & 0.402 & - & - \\
\hline & CS-63 & - & 0.037 & - & - & 0.023 & 0.079 & - & - & - & 0.535 & - & - \\
\hline Rebecca (Pavlova) salina & CS-49 & - & 0.031 & - & - & 0.021 & 0.051 & - & - & - & 0.399 & - & - \\
\hline Type 3 & & & & & & & & & & & & & \\
\hline Cricosphaera carterae & CS-40 & - & - & - & 0.003 & 0.101 & 0.091 & 0.027 & - & - & 0.449 & - & - \\
\hline Dicrateria inornata & CCMP355 & - & - & - & 0.002 & 0.088 & 0.049 & 0.017 & - & - & 0.254 & - & - \\
\hline & CS-254 & - & - & - & 0.003 & 0.064 & 0.032 & 0.014 & - & - & 0.291 & - & - \\
\hline Isochrysis galbana & CCMP1323 & - & - & - & - & 0.100 & 0.053 & 0.016 & - & - & 0.270 & - & - \\
\hline & CS-22 & - & - & - & 0.004 & 0.075 & 0.042 & 0.022 & - & - & 0.321 & - & - \\
\hline Isochrysis sp. & CS-177 & - & - & - & 0.005 & 0.130 & 0.093 & 0.033 & - & - & 0.468 & - & - \\
\hline Pseudoisochrysis paradoxa & CS-186 & - & - & - & 0.002 & 0.051 & 0.032 & 0.033 & - & - & 0.257 & - & - \\
\hline Type 4 & & & & & & & & & & & & & \\
\hline Prymnesium parvum & CCMP 708 & 0.099 & - & - & 0.010 & 0.066 & 0.109 & 0.032 & - & - & 0.512 & - & - \\
\hline & CS-345 & 0.085 & - & - & 0.007 & 0.043 & 0.080 & 0.022 & - & - & 0.569 & - & - \\
\hline Prymnesium patelliferum & CS-376 & 0.090 & - & 0.003 & 0.005 & 0.056 & 0.110 & 0.030 & - & - & 0.455 & - & - \\
\hline & CS-288 & 0.078 & - & 0.003 & 0.007 & 0.041 & 0.084 & 0.023 & - & - & 0.411 & - & - \\
\hline Prymnesium sp. & CS-458 & 0.069 & - & 0.003 & 0.003 & 0.027 & 0.071 & 0.021 & - & - & 0.469 & - & - \\
\hline Haptophyte 124 & CS-124 & 0.065 & - & - & 0.003 & 0.107 & 0.100 & 0.024 & - & - & 0.556 & - & - \\
\hline Type 5 & & & & & & & & & & & & & \\
\hline Ochrosphaera verrucosa & CCMP 594 & 0.052 & - & - & 0.009 & 0.111 & 0.215 & 0.016 & - & - & 0.351 & 0.038 & - \\
\hline Ochrosphaera neopolitana & CS-285 & 0.046 & - & - & 0.004 & 0.103 & 0.139 & 0.020 & - & - & 0.398 & 0.099 & - \\
\hline Haptophyte 260 & CS-260 & 0.048 & - & - & 0.005 & 0.102 & 0.139 & 0.019 & - & - & 0.434 & 0.033 & - \\
\hline Type 6 & & & & & & & & & & & & & \\
\hline Emiliania huxleyi & CCMP370 & 0.178 & - & 0.009 & 0.006 & 0.269 & - & 0.090 & - & 0.008 & 0.032 & 0.062 & 0.638 \\
\hline & CCMP 373 & 0.193 & - & 0.008 & 0.006 & 0.225 & - & 0.090 & - & - & 0.008 & - & 0.739 \\
\hline & CS-57 & 0.207 & - & 0.050 & 0.002 & 0.241 & - & 0.094 & - & 0.007 & 0.006 & - & 1.507 \\
\hline & CS-275-2 & 0.205 & - & 0.007 & 0.007 & 0.152 & - & 0.090 & - & 0.003 & 0.252 & 0.313 & 0.593 \\
\hline & CS-279 & 0.221 & - & 0.005 & 0.005 & 0.171 & - & 0.097 & - & - & 0.179 & 0.145 & 0.950 \\
\hline & CS-282 & 0.132 & - & 0.015 & - & 0.176 & - & 0.074 & - & - & 0.011 & - & 1.143 \\
\hline & CS-283 & 0.199 & - & - & 0.006 & 0.147 & - & 0.090 & - & - & 0.358 & 0.199 & 0.490 \\
\hline & CS-284 & 0.156 & - & 0.013 & 0.006 & 0.147 & - & 0.091 & - & - & 0.189 & 0.100 & 0.835 \\
\hline & CS-363 & 0.162 & - & - & 0.008 & 0.182 & - & 0.089 & - & - & 0.553 & 0.129 & 0.292 \\
\hline & CS-369 & 0.163 & - & 0.016 & 0.007 & 0.173 & - & 0.089 & - & - & 0.297 & 0.121 & 0.669 \\
\hline & CS-370 & 0.162 & - & 0.015 & 0.007 & 0.163 & - & 0.091 & - & - & 0.375 & 0.077 & 0.567 \\
\hline Gephyrocapsa oceanica & CS-335 & 0.189 & - & - & 0.004 & 0.145 & - & 0.081 & - & 0.008 & 0.285 & 0.254 & 0.447 \\
\hline Type 7 & & & & & & & & & & & & & \\
\hline Chrysochromulina camella & CS-268 & 0.214 & - & - & - & 0.094 & - & 0.031 & 0.027 & - & 0.608 & 0.266 & 0.044 \\
\hline Chrysochromulina ericina & CCMP 282 & 0.346 & - & - & 0.045 & 0.400 & - & 0.285 & - & 0.006 & 0.384 & 0.674 & 1.315 \\
\hline & CCMP 283 & 0.219 & - & - & 0.012 & 0.179 & - & 0.163 & - & - & 0.319 & 0.425 & 0.527 \\
\hline Chrysochromulina hirta & CS-228 & 0.207 & - & - & 0.006 & 0.134 & - & 0.134 & - & - & 0.425 & 0.379 & 0.321 \\
\hline Chrysochromulina kappa & CCMP 288 & 0.178 & - & - & 0.008 & 0.193 & - & 0.067 & - & 0.007 & 0.747 & 0.190 & 0.261 \\
\hline Chrysochromulina polylepis & CCMP286 & 0.219 & - & - & 0.014 & 0.166 & - & 0.002 & 0.067 & 0.006 & 0.124 & 0.084 & 1.107 \\
\hline Chrysochromulina strobilus & CS-231 & 0.194 & - & - & 0.003 & 0.123 & - & 0.025 & 0.031 & - & 0.751 & 0.129 & - \\
\hline Chrysochromulina sp. & CS-410 & 0.221 & - & - & 0.003 & 0.131 & - & 0.013 & 0.046 & 0.011 & 0.203 & 0.262 & 0.775 \\
\hline Type 8 & & & & & & & & & & & & & \\
\hline Dicrateria inornata & CS-267 & 0.236 & - & - & 0.006 & 0.081 & - & 0.058 & - & 0.266 & 0.036 & 0.106 & 0.694 \\
\hline Imantonia rotunda & CS-194 & 0.204 & - & - & 0.002 & 0.074 & - & 0.048 & - & 0.223 & 0.042 & 0.141 & 0.496 \\
\hline & CCMP 457 & 0.274 & - & 0.025 & 0.009 & 0.119 & - & 0.077 & - & 0.117 & 0.293 & 0.085 & 0.336 \\
\hline Phaeocystis antarctica & A $1-3$ & 0.110 & - & - & - & 0.239 & - & 0.033 & - & - & 0.102 & 0.055 & 0.296 \\
\hline & A $1-4$ & 0.062 & - & - & - & 0.199 & - & 0.031 & - & - & 0.065 & 0.050 & 0.344 \\
\hline & DE 10 & 0.077 & - & - & - & 0.197 & - & 0.025 & - & - & 0.072 & - & 0.222 \\
\hline & DE 12.1 & 0.156 & - & - & 0.002 & 0.183 & - & 0.067 & - & 0.169 & 0.012 & 0.005 & 1.052 \\
\hline & MSIA-1 & 0.153 & - & - & 0.004 & 0.189 & - & 0.067 & - & 0.120 & 0.532 & 0.029 & 0.020 \\
\hline & MSIA-2 & 0.161 & - & - & 0.003 & 0.144 & - & 0.067 & - & 0.196 & 0.521 & 0.039 & 0.065 \\
\hline & RG 1.2 & 0.091 & - & - & - & 0.219 & - & 0.029 & - & - & 0.032 & - & 0.343 \\
\hline & RG 2.2 & 0.142 & - & - & 0.003 & 0.144 & - & 0.054 & - & 0.080 & 0.011 & 0.007 & 0.918 \\
\hline & Т 4.1 & 0.123 & - & - & 0.004 & 0.170 & - & 0.063 & - & 0.111 & 0.398 & 0.035 & 0.384 \\
\hline & Т 9.1 & 0.109 & - & - & - & 0.273 & - & 0.035 & - & 0.022 & 0.104 & 0.066 & 0.284 \\
\hline Phaeocystis pouchetii & CS-165 & 0.218 & - & - & - & 0.118 & - & 0.056 & - & 0.270 & 0.166 & 0.133 & 0.333 \\
\hline Phaeocystis globosa & CCMP 627 & 0.200 & - & - & 0.016 & 0.213 & - & 0.035 & - & 0.007 & 0.223 & 0.051 & 0.155 \\
\hline
\end{tabular}


Table 4. Distribution of chlorophyll $c$ pigments across haptophyte families, showing families with designated pigment type and type species with characteristic pigment patterns. n: no. of species (strains); other abbreviations as in Table 2

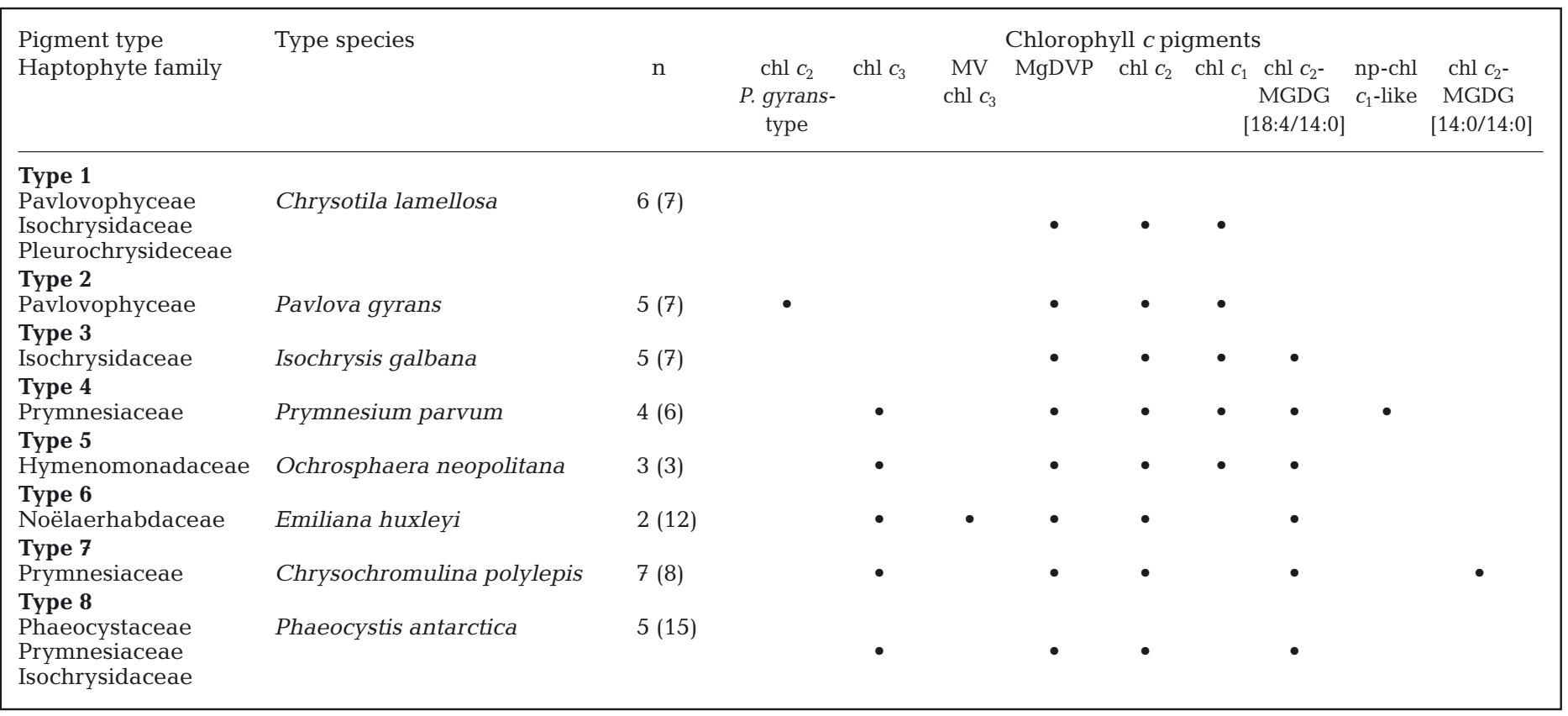

Table 5. Distribution of fucoxanthin derivatives across haptophyte families. tr: trace; further details as in Table 4

\begin{tabular}{|c|c|c|c|c|c|c|c|}
\hline \multirow{2}{*}{$\begin{array}{l}\text { Pigment type } \\
\text { Haptophyte family }\end{array}$} & \multirow[t]{2}{*}{ Type species } & \multicolumn{6}{|c|}{ Fucoxanthin derivatives } \\
\hline & & $\mathrm{n}$ & but-fuco & fuco & $\begin{array}{l}\text { 4-k-hex- } \\
\text { fuco }\end{array}$ & hex-fuco & 4-k-fuco \\
\hline \multicolumn{8}{|l|}{ Type 1} \\
\hline Pavlovophyceae & Chrysotila lamellosa & & & & & & \\
\hline $\begin{array}{l}\text { Isochrysidaceae } \\
\text { Pleurochrysideceae }\end{array}$ & & $6(7)$ & & $\bullet$ & & & \\
\hline \multicolumn{8}{|l|}{ Type 2} \\
\hline Pavlovophyceae & Pavlova gyrans & $5(7)$ & & $\bullet$ & & & \\
\hline \multicolumn{8}{|l|}{ Type 3} \\
\hline Isochrysidaceae & Isochrysis galbana & $5(7)$ & & $\bullet$ & & & \\
\hline \multicolumn{8}{|l|}{ Type 4} \\
\hline \multirow{2}{*}{\multicolumn{8}{|c|}{ Type 5}} \\
\hline & & & & & & & \\
\hline Hymenomonadaceae & Ochrosphaera neopolitana & $3(3)$ & & $\bullet$ & & & $\bullet$ \\
\hline \multicolumn{8}{|l|}{ Type 6} \\
\hline Noëlaerhabdaceae & Emiliana huxleyi & $2(12)$ & $\operatorname{tr}$ & $\bullet$ & $\bullet$ & $\bullet$ & \\
\hline \multicolumn{8}{|l|}{ Type 7} \\
\hline \multicolumn{8}{|l|}{ Type 8} \\
\hline Phaeocystaceae & Phaeocystis antarctica & $5(15)$ & - & - & - & - & \\
\hline Prymnesiaceae & & & & & & & \\
\hline
\end{tabular}

\section{Pigment types and haptophyte taxa}

The distribution of pigment types across the haptophyte classes, orders, families and genera are summarised in Table 8. Only 2 families of the 7 tested were characterised by a single pigment type: the Noëlaerhabdaceae (coccolithophorids; pigment Type 6) and the Hymenomonadaceae (pigment Type 5). In 2 cases, a single pigment type was restricted to a particular genus: Prymnesium (Type 4) and Chrysochromulina (Type 7). The remaining pigment types (Types 1, 2, 3, 6 and 8) were shared across several families and genera. Diacronema, Pavlova, Chrysotila and Pleurochrysis shared haptophyte Type 1 pigments (families Pavlo- 
Table 6. Chl $c$ pigments as mean percentages (range) of total chl $c$ in haptophyte pigment types (data from Table 3). n: no. of strains; abbreviations as in Table 2

\begin{tabular}{|c|c|c|c|c|c|c|c|c|c|}
\hline $\begin{array}{l}\text { Pigment } \\
\text { type }\end{array}$ & $\mathrm{n}$ & $\operatorname{chl} c_{1}$ & $\operatorname{chl} c_{2}$ & $\operatorname{chl} C_{3}$ & $\begin{array}{l}\text { Chl } c \text { pigme } \\
\text { chl } C_{2}- \\
\text { P. gyrans } \\
\text { type }\end{array}$ & $\begin{array}{l}\text { its } \\
\mathrm{MV} \text { chl } c_{3}\end{array}$ & MgDVP & $\begin{array}{c}\text { chl } C_{2}^{-} \\
\text {MGDG } \\
{[18: 4 / 14: 0]}\end{array}$ & $\begin{array}{c}\text { chl } C_{2^{-}} \\
\text {MGDG } \\
{[14: 0 / 14: 0]}\end{array}$ \\
\hline 1 & 7 & $\begin{array}{c}55 \\
(45-62.5)\end{array}$ & $\begin{array}{c}42 \\
(34-51)\end{array}$ & - & - & - & $\begin{array}{c}3 \\
(0-5.5)\end{array}$ & - & - \\
\hline 2 & 7 & $\begin{array}{c}53 \\
(49.5-59.5)\end{array}$ & $\begin{array}{c}17 \\
(12.2-20.4)\end{array}$ & - & $\begin{array}{c}28 \\
(21.7-35.9)\end{array}$ & - & $\begin{array}{c}2 \\
(0-3.0)\end{array}$ & - & - \\
\hline 3 & 7 & $\begin{array}{c}32 \\
(28.3-41.0)\end{array}$ & $\begin{array}{c}52 \\
43.2-59.1)\end{array}$ & - & - & - & $\begin{array}{c}2 \\
(0-2.8)\end{array}$ & $\begin{array}{c}14 \\
(9.5-15.4)\end{array}$ & - \\
\hline 4 & 6 & $\begin{array}{c}35 \\
(33.4-36.6)\end{array}$ & $\begin{array}{c}21 \\
(13.9-35.8)\end{array}$ & $\begin{array}{c}31 \\
(21.7-35.9)\end{array}$ & - & $\begin{array}{c}1 \\
(1.0-1.5)\end{array}$ & $\begin{array}{c}2 \\
(1.0-3.1)\end{array}$ & $\begin{array}{c}12 \\
(8.0-12.7)\end{array}$ & - \\
\hline 5 & 3 & $\begin{array}{c}47 \\
(44.4-53.3)\end{array}$ & $\begin{array}{c}31 \\
(27.5-33.0)\end{array}$ & $\begin{array}{c}14 \\
(12.9-15.3)\end{array}$ & - & - & $\begin{array}{c}2 \\
(1.3-2.2)\end{array}$ & $\begin{array}{c}6 \\
(4.0-6.4)\end{array}$ & - \\
\hline 6 & 12 & - & $\begin{array}{c}39 \\
(33.0-48.7)\end{array}$ & $\begin{array}{c}39 \\
32.2-45.1)\end{array}$ & - & $\begin{array}{c}2 \\
(1.0-8.4)\end{array}$ & $\begin{array}{c}1 \\
(0-1.8\end{array}$ & $\begin{array}{c}19 \\
(15.8-22.0)\end{array}$ & - \\
\hline 7 & 8 & - & $\begin{array}{c}33 \\
(25.7-43.4)\end{array}$ & $\begin{array}{c}45 \\
(32.2-58.5)\end{array}$ & - & - & $\begin{array}{c}2 \\
(0-4.2)\end{array}$ & $\begin{array}{c}15 \\
(3.1-28.4)\end{array}$ & $\begin{array}{c}5 \\
(0-14.3)\end{array}$ \\
\hline 8 & 15 & - & $\begin{array}{c}46 \\
(21.2-68.1)\end{array}$ & $\begin{array}{c}40 \\
(21.2-62.1)\end{array}$ & - & - & $\begin{array}{c}2 \\
(0-3.4)\end{array}$ & $\begin{array}{c}12 \\
(7.5-17.9)\end{array}$ & - \\
\hline
\end{tabular}

vaceae, Isochrysidaceae and Pleurochrysidaceae); Pavlova and Rebecca shared Type 2 pigments (family Pavlovaceae); Cricosphaera carterae (CS-40), Dicrateria inornata (CCMP 355, CS-254), Isochrysis and Pseudoisochrysis shared Type 3 pigments (family Isochrysidaceae), Emiliania and Gephyrocapsa shared Type 6 pigments (family Noëlaerhabdaceae), and Dicrateria inornata (CS-267), Imantonia and Phaeocystis strains shared Type 8 pigments (families Phaeocystaceae, Prymnesiaceae and Isochrysidaceae); 3 Dicrateria strains occurred across 2 pigment types, raising questions as to the true taxonomic identity of these strains. These examples show the variations in specificity of pigment types encountered in haptophyte taxa.

Table 7. Fucoxanthin pigments as mean percentages (range) of total fucoxanthins in haptophyte pigment types (data from Table 3). n: no. of strains; abbreviations as in Table 2

\begin{tabular}{|c|c|c|c|c|c|c|}
\hline \multirow{2}{*}{$\begin{array}{l}\text { Pigment } \\
\text { type }\end{array}$} & \multirow[t]{2}{*}{$\mathrm{n}$} & \multicolumn{5}{|c|}{ Fucoxanthin pigments } \\
\hline & & fuco & 4-k-fuco & hex-fuco & 4-k-hex-fuco & but-fuco \\
\hline 1 & 7 & 100 & - & - & - & - \\
\hline 2 & 7 & 100 & - & - & - & - \\
\hline 3 & 7 & 100 & - & - & - & - \\
\hline 4 & 6 & 100 & - & - & - & - \\
\hline 5 & 3 & $\begin{array}{c}88 \\
(80.1-93.0)\end{array}$ & $\begin{array}{c}12 \\
(7.0-19.9)\end{array}$ & - & - & - \\
\hline 6 & 12 & $\begin{array}{c}20.3 \\
(0.4-56.8)\end{array}$ & - & $\begin{array}{c}68.5 \\
(46.8-99.1)\end{array}$ & $\begin{array}{c}11.0 \\
(7.6-27.0)\end{array}$ & $\begin{array}{c}0.2 \\
(0.3-1.1)\end{array}$ \\
\hline 7 & 8 & $\begin{array}{c}39.7 \\
(9.4-84.8)\end{array}$ & - & $\begin{array}{c}37.3 \\
(0.7-83.8)\end{array}$ & $\begin{array}{c}22.7 \\
(6.3-33.7)\end{array}$ & $\begin{array}{c}0.3 \\
(0.2-0.9)\end{array}$ \\
\hline 8 & 15 & $\begin{array}{c}25.9 \\
(1.1-90.4)\end{array}$ & - & $\begin{array}{c}55.0 \\
(2.9-84.4)\end{array}$ & $\begin{array}{c}7.5 \\
(0-15.6)\end{array}$ & $\begin{array}{c}11.6 \\
(1.6-30.0)\end{array}$ \\
\hline
\end{tabular}

\section{Variation of pigments across strains of same species}

Emiliania huxleyi and Phaeocystis antarctica were 2 species tested for variations in pigment composition across strains; 11 strains of E. huxleyi showed a high coherence to pigment Type 6 composition (see Table 3), and $P$. antarctica (10 strains) closely matched haptophyte pigment Type 8 composition. However, significant variations in ratios of fucoxanthin and its acyloxy derivatives were found in 2 strains $E$. huxleyi and 2 strains of $P$. antarctica (Fig. 5). Again, several minor pigments were not detected in some strains, probably being present in quantities below limits of detection e.g. MV-Chl $c_{3}$, MgDVP and 4-keto-19'-hexanoyloxyfucoxanthin in E. huxleyi strains, and MgDVP, 19'hexanoyloxyfucoxanthin and 4-keto$19^{\prime}$-hexanoyloxyfucoxanthin in some strains of $P$. antarctica.

\section{DISCUSSION}

\section{New pigment types in the Haptophyta}

The present work has shown that 9 chlorophyll $c$ pigments and 5 fucoxanthin derivatives are key discriminators of 8 pigment types in 37 species (65 strains) of Haptophyta. The HPLC methods used (Garrido \& Zapata 1997, Zapata et al. 2000) allowed improved resolution of both polar and non-polar 
chlorophylls and carotenoids, compared to that of the widely used Wright et al. (1991) method, and other methods published in the last decade (see Jeffrey et al. 1999). The Wright et al. (1991) method distinguished 4 useful haptophyte pigment types based on the presence/absence of chl $C_{3}, 19$ '-hexanoyloxyfucoxanthin and 19'-butanoyloxyfucoxanthin (Jeffrey \& Wright 1994). These pigment types have been applied successfully in oceanographic studies to distinguish pigment (but not taxon) differences in haptophyte field populations (e.g. Mackey et al. 1996, 1998, Wright \& van den Enden 2000).

With 13 pigments now available for targeting haptophytes, resolution to families and even some genera in mixed phytoplankton populations is now possible using single pigments or pigment suites (see Tables $4,5 \& 8$ ). The $9 \mathrm{chl} c$ pigments formed 8 clear distribution patterns across the 65 strains (Table 4), while the fucoxanthin derivatives formed 4 distribution patterns across the strains (Table 5).

We will first discuss the validity of these pigment types in the light of current phylogenetic knowledge and then examine the extent of variability within the types under standard culture conditions, and how they may be modified in the natural environment. Finally we will consider the application of these pigment types as new markers for haptophytes in oceanographic field studies.

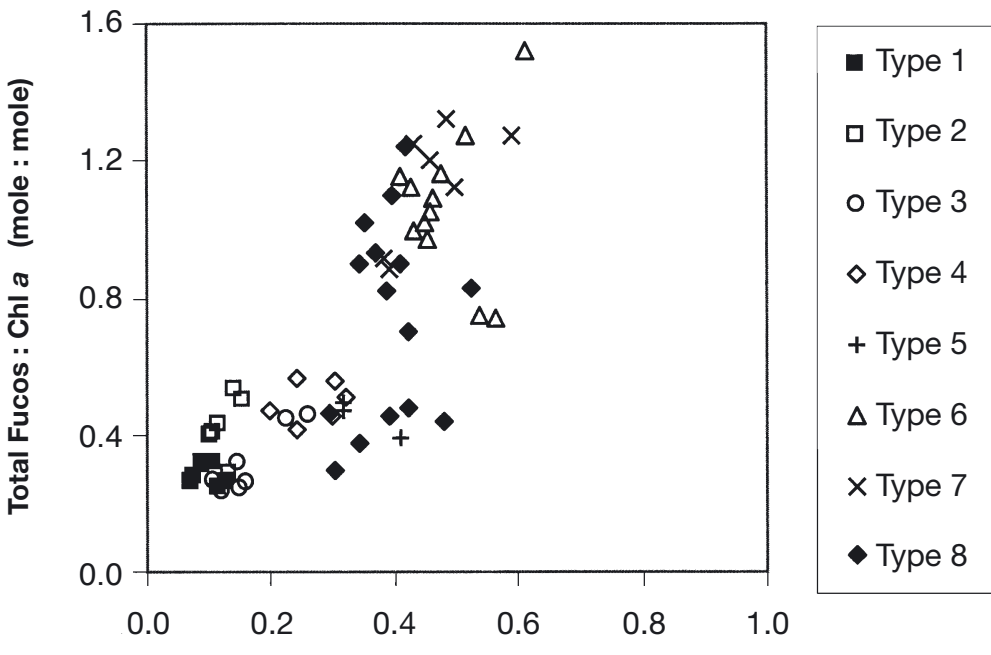

Total Chs $c$ :Chl a (mole : mole)

Fig. 4. Relationship between molar ratios of total fucoxanthins (Total fucos) and total chl $c$ pigments to chl a across all haptophyte pigment types (data from Table 3)

\section{Pigment types and haptophyte phylogeny}

Two lines of evidence suggest a strong genetic component to the differences we observed in pigment patterns within the Haptophyta. First, the cultures had been isolated from a wide range of locations that included most ocean basins (Table 1). All strains were grown under standard culture conditions for subtropical, temperate or polar species (e.g. light, day length and temperature) to minimise variations that might

Table 8. Distribution of pigment types across haptophyte taxa; + : present; -: absent

\begin{tabular}{|c|c|c|c|c|c|c|c|c|c|c|}
\hline \multirow[t]{2}{*}{ Order } & \multirow[t]{2}{*}{ Family } & \multirow[t]{2}{*}{ Genus } & \multicolumn{8}{|c|}{ Pigment types } \\
\hline & & & 1 & 2 & 3 & 4 & 5 & 6 & 7 & 8 \\
\hline \multicolumn{11}{|c|}{ Class Pavlovaceae } \\
\hline \multirow[t]{3}{*}{ Pavlovales } & Pavlovaceae & Diacronema & + & - & - & - & - & - & - & - \\
\hline & & Pavlova & + & + & - & - & - & - & - & - \\
\hline & & Rebecca & - & + & - & - & - & - & - & - \\
\hline \multicolumn{11}{|c|}{ Class Prymnesiophyceae } \\
\hline Phaeocystales & Phaeocystaceae & Phaeocystis & - & - & - & - & - & - & - & + \\
\hline \multirow[t]{3}{*}{ Prymnesiales } & Prymnesiaceae & Chrysochromulina & - & - & - & - & - & - & + & - \\
\hline & & Imantonia & - & - & - & - & - & - & - & + \\
\hline & & Prymnesium & - & - & - & + & - & - & - & - \\
\hline \multirow[t]{7}{*}{ Isochrysidales } & Isochrysidaceae & Chrysotila & + & - & - & - & - & - & - & - \\
\hline & & Cricosphaera & - & - & + & - & - & - & - & - \\
\hline & & Dicrateria & - & - & + & - & - & - & - & + \\
\hline & & Isochrysis & - & - & + & - & - & - & - & - \\
\hline & & Pseudoisochrysis & - & - & + & - & - & - & - & - \\
\hline & Noëlaerhabdaceae & Emiliania & - & - & - & - & - & + & - & - \\
\hline & & Gephyrocapsa & - & - & - & - & - & + & - & - \\
\hline \multirow[t]{2}{*}{ Coccolithales } & Pleurochrysidaceae & Pleurochrysis & + & - & - & - & - & - & - & - \\
\hline & Hymenomonadaceae & Ochrosphaera & - & - & - & - & + & - & - & - \\
\hline
\end{tabular}



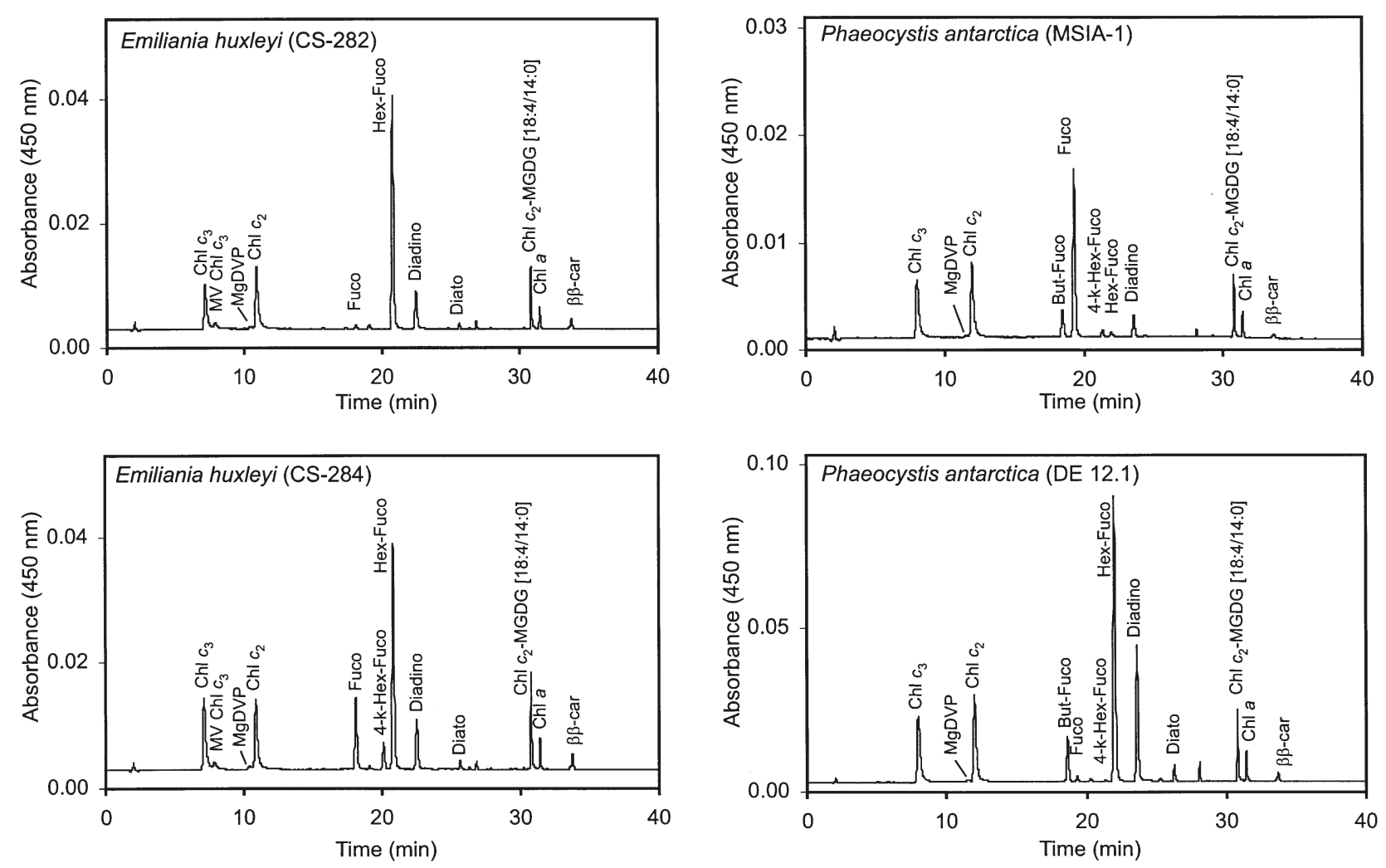

Fig. 5. Chromatograms (C8 HPLC method) showing differences in fucoxanthin and its acyloxyfucoxanthin derivatives in 2 strains of Emiliana huxleyi isolated from Sargasso Sea and 2 strains of Phaeocystis antarctica isolated from sea-ice (MSIA-1) and water column (DE12.1). Detection by absorbance at $450 \mathrm{~nm}$. Peak identifications as in Table 2

otherwise occur between strains due to growth conditions. Analytical procedures and harvest times were also standardised. The pigment types observed are therefore less influenced by 'environmentallyinduced' variability and should allow recognition of phylogenetic affinities among species.

Second, the 8 haptophyte pigment patterns identified here correlated closely with phylogenetic clades (Table 9) found in analysis of haptophyte 18S rDNA by Edvardsen et al. (2000). These authors established a tree using 25 identified haptophyte species (33 strains) in which 3 clades (A, [B1, B2], C) were within the Prymnesiophyceae, and 2 clades (D, E) were derived from amplified genes from phytoplankton taken from oligotrophic Pacific waters (presumably from closely related but unidentified members of Prymnesiophyceae). Members of the class Pavlovaceae formed a separate distinct group. (The Pavlovaceae were subsequently subdivided by Van Lenning et al. [2003], who found a tree structure that supported their 3 pigment types.)

Each pigment type was associated with only 1 clade, except for haptophyte pigment Type 8, which was found in 2 clades. Species containing pigment Type 5 were not included in the study of Edvardsen et al.
(2000). Unfortunately, the 2 studies used many different species. Our 37 species (65 strains) coincided with only 15 of the 25 identified species used by Edvardsen et al. (2000), and only 1 strain in both studies was identical. Similar genetic analysis is required for our 65 strains in order to confirm the genetic basis for our haptophyte

Table 9. Associations of haptophyte pigment types (present data) with haptophyte clades identified by analysis of $18 \mathrm{~S}$ rDNA by Edvardsen et al. (2000)

\begin{tabular}{|lll|}
\hline Clade & Typical genera & Pigment type \\
\hline Pavlovaceae & Pavlova & 2 \\
Prymnesiophyceae & Phaeocystis & 8 \\
Clade A & & \\
Clade B1 & Chrysochromulina & 7 \\
& Prymnesium & 4 \\
& Imantonia & 8 \\
Clade B2 & Chrysochromulina only & 7 \\
Clade C & Pleurochrysis & 1 \\
& Emiliania/Gephyrocapsa & 6 \\
Clade D & Isochrysis & 3 \\
Clade E & No cultured representatives & $?$ \\
& No cultured representatives & $?$ \\
\hline
\end{tabular}


pigment associations. In conclusion, we have some confidence in believing that our 8 haptophyte pigment types match phylogenetic trends among the species studied.

\section{Possible pigment functions}

Clear differences in relative quantities of the $9 \mathrm{chl} C$ pigments and 5 fucoxanthin derivatives across the 65 strains (Tables $6 \& 7$ ) probably result from functional differences between them.

Chlorophyll $\boldsymbol{c}$ pigments. It is generally accepted that Chls $C_{1}, C_{2}$ and $C_{3}$ have a light-harvesting role (Anderson \& Barrett 1986, Wilhelm \& Wiedemann 1991, Green \& Durnford 1996, Zapata et al. in press), and in our study these chl $c$ pigments were always present as a major proportion of the total chl $c$ (Table 6). The chl $C_{2}$-like Pavlova gyrans-type pigment, occurring in $35 \%$ of the total chl $c$ pigments, may also have a light-harvesting role (Fawley 1989). The occurrence of MgDVP in trace quantities in most haptophytes (Table 3) may signify its role as a biosynthetic intermediate in chlorophyll synthesis (Porra 1997, Porra et al. 1997). When present in larger quantities (e.g. in some prasinophytes), it occurs with chl $a$ and $b$ in the chlorophyll protein complexes and has a lightharvesting role (Brown 1985). The function of 2 other trace pigments, MV-Chl $C_{3}$ and chl $C_{2}$-MGDG [14:0/14:0], is unknown.

The newly discovered minor pigment $\mathrm{chl} C_{2}$-MGDG [18:4/14:0] may also have a light-harvesting role (J. L. Garrido pers. comm.) or it may function in the assembly of light-harvesting pigment complexes (Hoober \& Eggink 2001). It may act as a transporter of $\operatorname{chl} C_{2}$ from the MGDG-rich lipid bilayer of the inner chloroplast envelope membrane to its final location in the lightharvesting pigment protein complexes of the thylakoids (Jeffrey \& Anderson 2000). For a more complete discussion of chl $c$ chemistry, distribution and function, see Zapata et al. (in press).

Fucoxanthin derivatives. The light-harvesting roles of fucoxanthin and 19'-hexanoyloxyfucoxanthin were established by Sieferman-Harms (1985) and Haxo (1985), respectively. When present in significant quantities, 19'-butanoyloxyfucoxanthin may have a similar role. The function of the 4-keto derivatives is unknown. The universally distributed carotenoid pair diadinoxanthin and diatoxanthin, present in all haptophytes examined, have a well-established photoprotective function via the light-regulated epoxide cycle (Stransky \& Hager 1970, Siefermann-Harms 1985, Demmig-Adams \& Adams 1993, Moisan et al. 1998, Lohr \& Wilhelm 1999). Further study is needed to understand the function and biosynthetic regulation of all these important marine pigments, and their consequent reliability as chemotaxonomic indicators in field oceanography.

\section{Quantitative variation of chlorophyll $c$ and fucoxanthins across strains and pigment types}

The data in Tables $6 \& 7$ show that the patterns of relative abundance for $\mathrm{chl} c$ and fucoxanthins, respectively, are clear-cut, but there is considerable variation around the means for most pigments. While little is known of chl $C$ variability in haptophytes or other taxa, variation in fucoxanthins has previously been observed in haptophytes.

Wright \& Jeffrey (1987) gave a first indication of the variability of the relative proportions of fucoxanthin, 19'-hexanoyloxyfucoxanthin and 19'-butanoyloxyfucoxanthin in 4 different isolates of Phaeocystis spp. - 3 from the Southern Ocean (probably P. antarctica) and 1 from the East Australian Current (probably P. globosa; Medlin et al. 1994). This trend was confirmed in the present work, in which 11 strains of Emiliana huxleyi and 10 strains of $P$. antarctica were analysed (Tables $3 \& 7$ ).

While Emiliana huxleyi strains showed a strong coherence with haptophyte pigment Type 6, and those of Phaeocystis antarctica with pigment Type 8, variability in relative abundances of fucoxanthins and acyloxyfucoxanthins were indicated among the strains of both species (Tables $3 \& 7$, Fig. 5). These results do not deny the validity of the haptophyte pigment types, but point to the need to understand those factors that influence pigment variability within strains of the same species, isolated from different geographic areas, light fields or populations.

Confirmation of, and explanations for, fucoxanthin variability have been published in the past decade. Vaulot et al. (1994) observed 3 pigment clusters in 16 strains of Phaeocystis isolated mainly from temperate oceanic areas, supporting some of the present observations. In their Phaeocystis strains, both fucoxanthin and 19'-hexanoyloxyfucoxanthin were dominant or codominant, but 19'-butanoyloxyfucoxanthin in their study was never present except in minor or trace quantities. This pattern matches only 4 of our 11 Phaeocystis strains.

Jeffrey \& Wright (1994) found 1 strain of Phaeocystis sp. from the East Australian Current had fucoxanthin and lacked 19'-hexanoyloxyfucoxanthin, similar to the finding of Breton et al. (1999) and Cottonec et al. (2001) with northern hemisphere Phaeocystis spp. None of the strains examined in the present work matched this pigment pattern.

Fucoxanthin/acyloxyfucoxanthin variability was produced by iron limitation aided by light stress in 
1 Antarctic Phaeocystis strain (Van Leeuwe \& Stefels 1998). Iron limitation caused increased synthesis of 19'-hexanoyloxyfucoxanthin and 19'-butanoyloxyfucoxanthin at the expense of fucoxanthin. Buma et al. (1991) found differences in the 19'-hexanoyloxyfucoxanthin to chl a ratios in Phaeocystis strains isolated from both Antarctic and Atlantic ocean regions, and pigment ratios were also affected by experimental differences in growth phase, temperature, morphological cell type (flagellates or colonies) and variations in day/night cycles. Stolte et al. (2000) also found that 19'-hexanoyloxyfucoxanthin was synthesised from fucoxanthin, with light acting as a modulating factor, in strains of Emiliania huxleyi grown under conditions of light, phosphate and nitrate limitation.

The relative importance of nutritional, environmental and genetic factors influencing fucoxanthin variability needs to be fully evaluated in order to define the reliability of fucoxanthins as indicators of algal types in the field.

\section{Comparison with previous surveys of Haptophyta}

Table 10 highlights the advances in a comparison of the 8 haptophyte pigment types identified in the present work with the 4 of Jeffrey \& Wright (1994). The earlier study could not distinguish the pigmentation of diatoms from that of 16 of 50 haptophyte strains studied (32\%, their type 1). Most of these can now be distinguished by the presence of chl $\mathrm{C}_{2}$ Pavlova gyrans-type and Chl $c_{2}$-MGDG [18:4/14:0] and fall within the new haptophyte pigment Types 2 and 3 , respectively, with only 7 of the 65 haptophyte strains $(11 \%)$ remaining in Type 1 . Similarly, those taxa previously classified by Jeffrey \& Wright (1994) as type 2 can now be further subdivided by the pres- ence of chl $C_{2}$-MGDG [18:4/14:0] and non-polar chl $C_{1}$ (new Type 4) and 4-keto-fucoxanthin (new Type 5), respectively. The former type 3 of Jeffrey \& Wright (1994) can now be subdivided into new Type 6 and new Type 7 on the basis of MV-chl $c_{3}$ and chl $c_{2}$ MGDG [14:0/14:0], respectively. Type 4 of Jeffrey \& Wright (1994) could not be further subdivided (new haptophyte pigment Type 8), although chl $C_{2}$-MGDG [18:4/14:0] was recognised as an additional characteristic.

\section{Application of haptophyte pigment signatures in oceanography}

The additional pigments and pigment patterns identified in this study add power to biological oceanographic studies where one must detect algal pigment signatures in the presence of other taxa, some of which have potentially overlapping pigment compositions.

The recent analysis of 9 species from the Pavlovaceae by Van Lenning et al. (2003) found 3 pigment types: A, B, C. While not all species tested were common to our study, it is clear that their Pavlovophyceae pigment type A corresponds with our Type 1, and their type B with our Type 2, with no irregularities. Their type $\mathrm{C}$ was based on the presence of an additional pigment (thought to be the monovinyl form of chl $C_{2}$ Pavlova gyrans-type) that was found in a single species, Exanthemachrysis gayraliae, which unfortunately was not included in our survey. However this pigment appears to be a useful additional marker.

Several of the new marker pigments discussed above are restricted to particular taxa and may be useful for their detection in mixed populations. Of particular interest is $\mathrm{MV}$-chl $\mathrm{C}_{3}$, a minor pigment strongly associated with the globally important species

Table 10. Comparison of Jeffrey \& Wrights' (1994) haptophyte pigment types (1 to 4), with Types 1 to 8 found in present work. tr: trace; further abbreviations as in Table 2

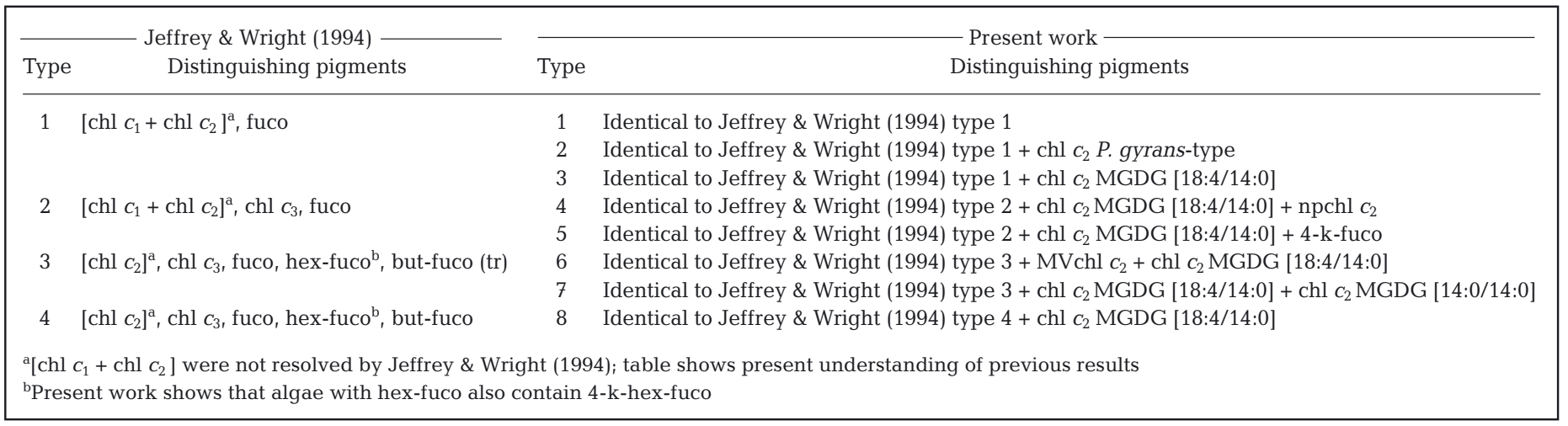


Emiliania huxleyi. This pigment and E. huxleyi cell counts were recently targeted in a Southern Ocean Transect (Wright unpubl.). Although cell numbers were low (263 cells $\mathrm{ml}^{-1}$ maximum), MV-chl $\mathrm{c}_{3}$ was detected at a low concentration. However, an unknown co-chromatographing compound prevented reliable quantitation. $\mathrm{MV}-\mathrm{Chl} \mathrm{C}_{3}$ may only be a useful marker in field samples under bloom conditions (when cell concentrations may exceed $10000 \mathrm{ml}^{-1}$; Tyrrell \& Taylor 1995).

Three other pigments, chl $\mathrm{c}_{2}$ Pavlova gyrans-type, chl $C_{2}$-MGDG [14:0/14:0], and 4-keto-fucoxanthin, occur in higher concentrations than $\mathrm{MV}-\mathrm{chl} \mathrm{C}_{3}$ and appear to be excellent indicators for members of the genera Pavlova, Chrysochromulina and Ochrosphaera, respectively. Absence of these pigments however is inconclusive, since the first 2 pigments were not detected in all members of their respective genera. Similarly, while 4-ketofucoxanthin was not found outside the genus Ochrosphaera, it cannot be assumed to be universally present within the genus on the basis of only 2 species tested here.

Interpretation of field data is complicated by the fact that pigment ratios are variable, even under controlled growth conditions, and some markers are sometimes below detection limits or absent from their typical species. Some of the characteristic pigments described above were in low concentrations in algal cultures and may be insignificant in mixed field populations unless their source-species are in bloom. Pigment ratios are also strongly influenced by light intensity (and hence depth and season) and nutrient status.

Light intensities for culture growth in this study were kept constant (at 60 to $70 \mu \mathrm{mol}$ quanta $\mathrm{m}^{-2} \mathrm{~s}^{-1}$, except for Phaeocystis antarctica, $40 \mu \mathrm{mol}$ quanta $\mathrm{m}^{-2} \mathrm{~s}^{-1}$ ) so that genetic differences between strains could readily be observed. However phytoplankton in the field will experience a range of light intensities and adjust their pigment composition accordingly. The ratios determined in this paper will serve as a starting point for interpreting field samples, but the actual pigment ratios in the field will need to be retrieved from the data using a programme such as CHEMTAX (Mackey et al. 1996) after subdividing the data into depth layers to allow for differences in irradiance with depth.

While the unambiguous markers identified above may serve as indicators for the presence of certain taxa, determining the relative abundance of these and other groups in the planktonic community requires analysis of pigment suites (Jeffrey et al. 1999) representing the major species present. This cannot be done manually; it requires computer methods such as CHEMTAX (Mackey et al. 1996) to determine the pigment ratios for particular taxa and the relative abundances of those taxa in a set of field samples.

\section{Endosymbioses and similarly pigmented non-haptophyte taxa}

It is now generally accepted that the photosynthetic apparatus originated from a primary endosymbiosis between a cyanobacterium and a non-photosynthetic phagotrophic eucaryote (McFadden 2001 [review], Palmer 2003) that subsequently evolved to green, red and glaucophyte algal types (Moreira et al. 2000). Recent analyses of certain nuclear and chloroplast genes support the hypothesis of Cavalier-Smith (2002) that the chloroplasts of heterokonts, haptophytes, cryptophytes and dinoflagellates all arose from a common secondary endosymbiosis involving a red alga. Primary, secondary and tertiary symbioses with secondary plastid replacements, resulting in evolution of diverse pigment types, were convincingly demonstrated by Palmer (2003). For example, certain modern dinoflagellates that have evolved by secondary chloroplast replacement and tertiary endosymbioses have lost their original primitive red algal plastids and now have plastids of either chlorophyte or haptophyte origin (see Jeffrey \& Vesk 1997, Tengs et al. 2000).

By this mechanism, pigment suites from haptophyte taxa may now be found in present-day oceans in some non-haptophyte taxa (Jeffrey \& Vesk 1997). This can present difficulties in the interpretation of pigment profiles in the field. For example, Table 11 shows that most diatoms (examined by earlier methods) have the same pigment composition as those of haptophyte pigment Type 1, with $\operatorname{chl} C_{1}, C_{2}$ and fucoxanthin as major pigments (Stauber \& Jeffrey 1988). Chl $c_{3}$ also replaced chl $c_{1}$ in 5 tropical pennate diatoms. Type 2 haptophyte pigments have recently been found in both the toxic

Table 11. Haptophyte pigment types (present work) compared with those of similarly pigmented non-haptophyte algal taxa

Type Non-haptophyte algal taxa with similar pigment pattern (representative species)

1 Diatoms (e.g. Phaeodactylum tricornutum) ${ }^{\mathrm{a}}$

2 Diatoms (e.g. Pseudo-nitzschia multiseries, CCMP 1659) ${ }^{\mathrm{b}}$

Fucoxanthin-containing dinoflagellates (e.g. Peridinium foliaceum $)^{\mathrm{c}}$

$3 \quad$ No other algal group has this pigment pattern No other algal group has this pigment pattern No other algal group has this pigment pattern No other algal group has this pigment pattern Some fucoxanthin-containing dinoflagellates (e.g. Karenia brevis) ${ }^{\text {b }}$

No other algal group has this pigment pattern

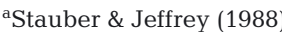

bZapata et al. (1998)

'Zapata (unpubl.) 
diatom Pseudo-nitzschia multiseries (Table 11), and the fucoxanthin-containing dinoflagellates Peridinium (=Kryptoperidinium) balticum and P. foliaceum (now either allocated in Peridiniopsis or Durinskia: Carty \& Cox 1986). These dinoflagellates are known from electron microscopical studies and ribosomal RNA analysis to harbour a diatom endosymbiont (Tomas \& Cox 1973, Jeffrey \& Vesk 1976, Chesnick et al. 1997). A dinoflagellate with 19'-acyloxyfucoxanthins (Karenia brevis: Zapata et al. 1998) contains 19'-hexanoyloxyfucoxanthin, 4-keto-19'-hexanoyloxyfucoxanthin, chl $c_{3}$, chl $c_{2}$ MGDG [18:4/14:0] and chl $C_{2}$-MGDG [14:0/14:0], indicating the presence of an endosymbiont with haptophyte Type 7 pigments. A similar dinoflagellate, Karlodinium sp., has similar pigments but lacks chl $C_{2}$ MGDG [14:0/14:0].

Diatoms and fucoxanthin-containing dinoflagellates share haptophyte pigment Types 1 and 2 with members of the Pavlovaceae (Table 8), and dinoflagellates with 19'-acyloxyfucoxanthins share pigment Type 7 with Chrysochromulina species (Prymnesiaceae). At the present state of knowledge, haptophyte pigment Types 3,4 , 5, 6 and 8 are not known for other algal groups, and currently provide a unique 'tag' for those haptophyte taxa containing these pigment suites (see Tables 4,5 \& 8).

The complexity of pigment patterns and the complications of endosymbiotic plastids do not allow reliance on pigment data alone. To distinguish these similarly pigmented microalgae in field observations, it is essential that simultaneous microscopic examinations of representative phytoplankton samples are carried out (Thomsen et al. 1994, Wright et al. 1996).

\section{Recommendations}

Detection of the new diagnostic haptophyte pigments requires the use of high-resolution HPLC techniques (e.g. Zapata et al. 2000), since they cannot be adequately resolved by earlier techniques (e.g. Wright et al. 1991). Their potentially low concentrations require that sample collection and analysis are optimised for high sensitivity (fluorescence detection for chlorophylls) as well as maximum resolution (i.e. large filtration volumes, small filters, and small extraction and injection volumes). It must also be recognised that cis-carotenoids and chlorophyll degradation products may confuse the interpretation of minor pigments and methods should be optimised to minimize their formation. Measuring the response of pigment ratios to changing irradiances in the field will improve interpretation of ocean transects. Finally, cultured representatives of all other algal classes, should now be examined by the new HPLC methods, to determine whether the new pigments are restricted to the Haptophyta, or are more widely distributed.
Acknowledgements. We wish to thank CSIRO Marine Research staff, Ms J.M. LeRoi and Ms C. Johnston, for expert culturing of the microalgae, our colleagues Professor H.J. Marchant and Associate Professor G. M. Hallegraeff for helpful comments on the manuscript and Ms A. Pirrone for assistance with the word-processing.

\section{LITERATURE CITED}

Andersen RA, Bidigare RR, Keller MD, Latasa M (1996) A comparison of HPLC pigment signatures and electron microscopic observations for oligotrophic waters of the North Atlantic and Pacific Oceans. Deep-Sea Res II 43: 517-537

Anderson JM, Barrett J (1986) Light-harvesting pigment and protein complexes of algae. In: Staehelin LA and Arntzen CAJ (eds) Photosynthesis. III. Membranes and light-harvesting systems. Springer-Verlag, Berlin, p 269-285

Bjørnland T (1997) UV-Vis spectroscopy In: Jeffrey SW, Mantoura RFC, Wright SW (eds) Phytoplankton pigments in oceanography: guidelines to modern methods. UNESCO, Paris, p 578-594

Bjørnland T, Liaaen-Jensen S (1989) Distribution patterns of carotenoids in relation to chromophyte phylogeny and systematics. In: Green JC, Leadbeater BSC, Diver WL (eds) The chromophyte algae: problems and perspectives. Clarendon Press, Oxford, p 37-61

Breton E, Sartour B, Brylinski JM (1999) No feeding on Phaeocystis sp. as solitary cells (post-bloom period) by the copepod Temora longicornis in the coastal waters of the English Channel. Hydrobiologia 414:13-23

Brown JS (1985) Three photosynthetic antenna porphyrins in a primitive green alga. Biochim Biophys Acta 807:143-146

Brown CW, Yoder JA (1994) Blooms of Emiliania huxleyi (Prymnesiophyceae) in surface waters of the Nova Scotian shelf and the Grand Bank. J Plankton Res 15:1429-1438

Buma AGJ, Bano N, Veldhuis MJW, Kraay GW (1991) Comparison of the pigmentation of two strains of the prymnesiophyte Phaeocystis sp. Neth J Sea Res 27:173-182

Carty S, Cox ER (1986) Kansodinium gen. nov. and Durinskia gen. nov.: two genera of freshwater dinoflagellates (Pyrrhophyta). Phycologia 25:197-204

Cavalier-Smith T (2002) Chloroplast evolution: secondary symbiogenesis and multiple losses. Curr Biol 12:62-64

Chesnick JM, Kooistra WHFC, Wellbrock U, Medlin LK (1997) Ribosomal RNA analysis indicates a benthic pennate diatom ancestry for the endosymbionts of the dinoflagellates Peridinium foliaceum and Peridinium balticum (Pyrrhophyta). J Eucaryot Microbiol 44:314-320

Cotonnec G, Brunet C, Sautour B, Thoumelin G (2001) Nutritive value and selection of food particles by copepods during a spring bloom of Phaeocystis sp. in the English Channel, as determined by pigment and fatty acid analyses. J Plankton Res 23:693-703

CSIRO (Commonwealth Scientific and Industrial Research Organisation) (1998) The CSIRO collection of living microalgae: strain list. 11pp

Demmig-Adams B, Adams WW (1993) The xanthophyll cycle. In: Young A, Britton G (eds) Carotenoids in photosynthesis. Chapman \& Hall, London, p 206-251

Edvardsen B, Eikrem W, Green JC, Andersen B, Moon-Van der Staay SY, Medlin L (2000) Phylogenetic reconstruction of the Haptophyta inferred from 18S ribosomal DNA sequences and available morphological data. Phycologia 39:19-35

Egeland ES, Garrido JL, Zapata M, Maestro MA, Liaaen- 
Jensen S (2000) Algal carotenoids. Part 64. Structure and chemistry of 4-keto-19'-hexanoyloxyfucoxanthin with a novel carotenoid end group. J Chem Soc Perkin Trans I, 8: $1223-1230$

Fawley MW (1989) A new form of chlorophyll $C$ involved in light harvesting. Plant Physiol (Rockville) 91:727-732

Fookes CJR, Jeffrey SW (1989) The structure of chlorophyll $C_{3}$, a novel marine photosynthetic pigment. J Chem Soc Chem Commun 23:1827-1828

Garrido JL, Zapata M (1997) Reversed-phase high-performance liquid chromatography of mono- and divinylchlorophyll forms using pyridine-containing mobile phases and polymeric octadecylsilica. Chromatographia $44: 43-49$

Garrido JL, Otero J, Maestro MA, Zapata M (2000) The main non-polar chlorophyll $c$ from Emiliania huxleyi (Prymnesiophyceae) is a chlorophyll $C_{2}$-monogalactosyldiacylglyceride ester: a mass spectrometry study. J Phycol 36: 497-505

Green BR, Durnford DG (1996) The chlorophyll-carotenoid proteins of oxygenic photosynthesis. Annu Rev Plant Physiol Plant Mol Biol 47:685-714

Guillard RRL (1975) Culture of phytoplankton for feeding marine invertebrates. In: Smith WL, Chanley M (eds) Culture of marine invertebrate animals. Plenum Press, New York, p 29-60

Guillard RRL, Hargraves PE (1993) Stichochrysis immobilis is a diatom not a chrysophyte. Phycologia 32:234-236

Guillard RRL, Ryther JH (1962) Studies of marine plankton diatoms. I. Cyclotella nana Hustedt and Detonula confervacea (Cleve) Gran. Can J Microbiol 8:229-239

Haxo FT (1985) Photosynthetic action spectrum of the coccolithophorid Emiliania huxleyi: (Haptophyceae): 19'-hexanoyloxyfucoxanthin as antenna pigment. J Phycol 21: 282-287

Heimdal BR (1997) Modern coccolithophorids. In: Tomas CR (ed) Marine phytoplankton: a guide to naked flagellates and coccolithophorids, Academic Press, London, $p$ 147-247

Helfrich M, Ross A, King GC, Turner AG, Larkum AWD (1999) Identification of [8-vinyl]-protochlorophyllide $a$ in phototrophic prokaryotes and algae: chemical and spectroscopic properties. Biochim Biophys Acta 1410:262-272

Hoober JK, Eggink LL (2001) A potential role of chlorophylls $b$ and $c$ in assembly of light-harvesting complexes. FEBS Lett 489:1-3

Jeffrey SW (1989) Chlorophyll $c$ pigments and their distribution in the chromophyte algae. In: Green JC, Leadbeater BSC, Diver WL (eds) The chromophyte algae: problems and perspectives. Clarendon Press, Oxford, p 13-36

Jeffrey SW (1997a) Structural relationships between algal chlorophylls. In: Jeffrey SW, Mantoura RFC, Wright SW (eds) Phytoplankton pigments in oceanography: guidelines to modern methods. UNESCO monographs on oceanographic methodology, Vol 10. UNESCO, Paris, p $566-571$

Jeffrey SW (1997b) Chlorophyll and carotenoid extinction coefficients. In: Jeffrey SW, Mantoura RFC, Wright SW (eds) Phytoplankton pigments in oceanography: guidelines to modern methods, UNESCO monographs on oceanographic methodology, Vol 10. UNESCO, Paris, p 595-596

Jeffrey SW, Anderson JM (2000) Emiliania huxleyi (Haptophyta) holds promising insights for photosynthesis. J Phycol 35:449-452

Jeffrey SW, LeRoi JM (1997) Simple procedures for growing SCOR reference microalgal cultures. In: Jeffrey SW, Mantoura RFC, Wright SW (eds) Phytoplankton pigments in oceanography: guidelines to modern methods, UNESCO monographs on oceanographic methodology, Vol 10. UNESCO, Paris, p 181-205

Jeffrey SW, Mantoura RFC (1997a) Pigment abbreviations used by SCOR WG 78. In: Jeffrey SW, Mantoura RFC, Wright SW (eds) Phytoplankton pigments in oceanography: guidelines to modern methods, UNESCO monographs on oceanographic methodology, Vol 10. UNESCO, Paris, p 564-565

Jeffrey SW, Mantoura RFC (1997b) Minimum criteria for identifying phytoplankton pigments. In: Jeffrey SW, Mantoura RFC, Wright SW (eds) Phytoplankton pigments in oceanography: guidelines to modern methods, UNESCO monographs on oceanographic methodology, Vol 10. UNESCO, Paris, p 631-632

Jeffrey SW, Vesk M (1976) Further evidence for a membranebound endosymbiont within the dinoflagellate Peridinium foliaceum. J Phycol 12:450-455

Jeffrey SW, Vesk M (1997) Introduction to marine phytoplankton and their pigment signatures. In: Jeffrey SW, Mantoura RFC, Wright SW (eds) Phytoplankton pigments in oceanography: guidelines to modern methods, UNESCO monographs on oceanographic methodology, Vol 10. UNESCO, Paris p 37-84

Jeffrey SW, Wright SW (1987) A novel spectrally distinct component in preparations of chlorophyll $c$ from the microalga Emiliania huxleyi (Prymnesiophyceae). Biochim Biophys Acta 894:180-184

Jeffrey SW, Wright SW (1994) Photosynthetic pigments in the Haptophyta. In: Green JC, Leadbeater BSC (eds) The haptophyte algae. Clarendon Press, Oxford, p 111-132

Jeffrey SW, Wright SW (1997) Qualitative and quantitative HPLC analysis of SCOR reference algal cultures. In: Jeffrey SW, Mantoura RFC, Wright SW (eds) Phytoplankton pigments in oceanography: guidelines to modern methods, UNESCO monographs on oceanographic methodology, Vol 10. UNESCO, Paris, p 343-360

Jeffrey SW, Mantoura RFC, Bjørnland T (1997a) Data for the identification of 47 key phytoplankton pigments. In: Jeffrey SW, Mantoura RFC, Wright SW (eds) Phytoplankton pigments in oceanography: guidelines to modern methods, UNESCO monographs on oceanographic methodology, Vol 10. UNESCO, Paris, p 449-559

Jeffrey SW, Mantoura RFC, Wright SW (eds) (1997b) Phytoplankton pigments in oceanography: guidelines to modern methods, UNESCO monographs on oceanographic methodology, Vol 10, UNESCO, Paris

Jeffrey SW, Wright SW, Zapata M (1999) Recent advances in HPLC pigment analysis of phytoplankton. Mar Freshw Res 50:879-896

Jordan RW, Kleijne A, Heimdal BR, Green JC (1995) A glossary of the extant Haptophyta of the world. J Mar Biol Assoc UK 74:769-814

Keller MD, Selvin RC, Claus W, Guillard RRL (1987) Media for the culture of oceanic ultraphytoplankton. J Phycol 23: $633-638$

Loeblich AR (1975) A seawater medium for dinoflagellates and the nutrition of Cachonia niei. J Phycol 11:80-86

Lohr M, Wilhelm C (1999) Algae displaying the diadinoxanthin cycle possess the violaxanthin cycle. Proc Natl Acad Sci USA 96:8784-8798

Mackey MD, Mackey DJ, Higgins HW, Wright SW (1996) CHEMTAX - a program for estimating class abundance from chemical markers: application to HPLC measurements of phytoplankton. Mar Ecol Prog Ser 144:265-283

Mackey DJ, Higgins HW, Mackey MD, Holdsworth D (1998) Algal class abundances in the western Equatorial Pacific: 
estimation from HPLC measurements of chloroplast pigments using CHEMTAX. Deep-Sea Res II 45:1441-1468

Malin G, Liss PS, Turner SM (1994) Dimethyl sulfide: production and atmospheric consequences. The haptophyte algae. Clarendon Press, Oxford, p 303-320

McFadden GI (2001) Primary and secondary endosymbiosis and the origin of plastids. J Phycol 37:951-959

Medlin LK, Lange M, Baumann MEM (1994) Genetic differentiation among three colony-forming species of Phaeocystis: further evidence for the phylogeny of the Prymnesiophyta. Phycologia 33:199-212

Moestrup Ø (1994) Economic aspects: 'blooms', nuisance species, and toxins. In: Green JC, Leadbeater BSC (eds) The haptophyte algae. Clarendon Press, Oxford, p 265-285

Moisan TA, Olaizola M, Mitchell BG (1998) Xanthophyll cycling in Phaeocystis antarctica: changes in cellular fluorescence. Mar Ecol Progr Ser 169:113-121

Moreira D, Le Guyader H, Philippe H (2000) The origin of red algae and the evolution of chloroplasts. Nature 405:69-72

Nelson JR, Wakeham SG (1989) A phytol-substituted chlorophyll $c$ from Emiliania huxleyi (Prymnesiophyceae). J Phycol 25:761-766

Okada H, McIntyre A (1977) Seasonal distribution of the modern coccolithophores in the Western North Atlantic Ocean. Mar Biol 54:319-328

Paasche E (2002) A review of the coccolithophorid Emiliania huxleyi (Prymnesiophyceae), with particular reference to growth, coccolith formation, and calcification-photosynthesis interactions. Phycologia 40:503-529

Palmer JD (2003) The symbiotic birth and spread of plastids: how many times and whodunit? J Phycol 39:4-11

Porra RJ (1997) Recent progress in porphyrin and chlorophyll biosynthesis. Photochem Photobiol 65:492-516

Porra RJ, Pfündel EE, Engel N (1997) Metabolism and function of photosynthetic pigments. In: Jeffrey SW, Mantoura RFC, Wright SW (eds) Phytoplankton pigments in oceanography: guidelines to modern methods, UNESCO monographs on oceanographic methodology, Vol 10. UNESCO, Paris, p 85-126.

Siefermann-Harms D (1985) Carotenoids in photosynthesis. I. Location in photosynthetic membranes and light-harvesting function. Biochim Biophys Acta 811:325-355

Stauber JL, Jeffrey SW (1988) Photosynthetic pigments in fifty-one species of marine diatoms. J Phycol 24:158-172

Stolte W, Kraay GW, Noodeloos AAM, Riegman R (2000) Genetic and physiological variation in pigment composition of Emiliania huxleyi (Prymnesiophyceae) and the potential use of its pigment ratios as a quantitative physiological marker. J Phycol 36:529-539

Stransky H, Hager A (1970) Das Carotinoidmuster und die Verbreitung des lichtinduzierten Xanthophyllcyclus in verschiedenen Algenklassen. Arch Mikrobiol 73:315-323

Tengs T, Dahlberg OJ, Schalchian-Tabrizi K, Klaveness D, Rudi K, Delwiche CF, Jakobsen KS (2000) Phylogenetic analyses indicate that the 19'-hexanoyloxyfucoxanthincontaining dinoflagellates have tertiary plastids of haptophyte origin. Mol Biol Evol 17:718-729

Thomsen HA, Buck KR, Chavez FP (1994) Haptophytes as components of marine phytoplankton. In: Green J, Leadbeater B (eds) The haptophyte algae, Oxford University Press, Oxford, p 187-208

Tomas RN, Cox ER (1973) Observations on the symbiosis of Peridinium balticum and its intracellular alga. I. Ultrastructure. J Phycol 9:304-323

Tyrrell T, Taylor AH (1995) A modelling study of Emiliania huxleyi in the NE Atlantic. J Mar Syst 9:83-112

Van der Wal P, Kempers RS, Veldhuis MJW (1995) Production and downward flux of organic matter and calcite in a North Sea bloom of the coccolithophore Emiliania huxleyi. Mar Ecol Prog Ser 126:247-265

Van Leeuwe MA, Stefels J (1998) Effects of iron and light stress on the biochemical composition of Antarctic Phaeocystis sp. (Prymnesiophyceae). II. Pigment composition. J Phycol 34:496-503

Van Lenning K, Latasa M, Estrada M, Sáez AG, Medlin L, Probert I, Véron B, Young J (2003) Pigment signatures and phylogenetic relationships of the Pavlovophyceae (Haptophyta). J Phycol 39:379-389

Vaulot D, Birrien JL, Marie D, Casotti R, Veldhuis MJW, Kraay GW, Chrétiennot-Dinet MJ (1994) Morphology, ploidy, pigment composition, and genome size of cultured strains of Phaeocystis (Prymnesiophyceae). J Phycol 30:1022-1035

Westbroek P, van Hinte JE, Brummer GJ, Veldhuis M, Brownlee C, Green JC, Harris R, Heimdal BR (1994) Emiliania huxleyi as a key to biosphere-geosphere interactions. In: Green J, Leadbeater B (eds) The haptophyte algae. Oxford University Press, Oxford, p 321-334

Wilhelm C, Wiedemann T (1991) Evidence of protein bound chlorophyll $C_{3}$ in a light-harvesting protein isolated from the flagellate alga Prymnesium parvum (Prymnesiophyceae). Photosynthetica 25:249-255

Wright SW, Jeffrey SW (1987) Fucoxanthin pigment markers of marine phytoplankton analysed by HPLC and HPLTC. Mar Ecol Prog Ser 38:259-266

Wright SW, van den Enden RL (2000) Phytoplankton community structure and stocks in the East Australian marginal ice zone (BROKE survey, January-March 1996) determined by CHEMTAX analysis of HPLC pigment signatures. Deep-Sea Res II 47:2363-2400

Wright SW, Jeffrey SW, Mantoura RFC, Llewellyn CA, Bjørnland T, Repeta D, Welschmeyer N (1991) Improved HPLC method for the analysis of chlorophylls and carotenoids from marine phytoplankton. Mar Ecol Prog Ser 77:183-196

Wright SW, Thomas DP, Marchant HJ, Higgins HW, Mackey MD, Mackey DJ (1996) Analysis of phytoplankton of the Australian sector of the Southern Ocean: comparisons of microscopy and size-frequency data with interpretations of pigment HPLC data using the CHEMTAX matrix factorisation program. Mar Ecol Prog Ser 144:285-298

Zapata M, Garrido JL (1991) Influence of injection conditions in reversed-phase high-performance liquid chromatography of chlorophylls and carotenoids. Chromatographia 31: 589-594

Zapata M, Freire J, Garrido JL (1998) Pigment composition of several harmful algae determined by HPLC using pyridine-containing mobile phase and a polymeric octadecylsilica column. In: Reguera B, Blanco J, Fernández ML, Wyatt T (eds) Harmful algae. Xunta de Galicia and Intergovernmental Oceanographic Commission of UNESCO, Santiago de Compostele, p 304-307

Zapata M, Rodríguez F, Garrido JL (2000) Separation of chlorophylls and carotenoids from marine phytoplankton: a new HPLC method using a reversed phase $\mathrm{C}_{8}$ column and pyridine-containing mobile phases. Mar Ecol Prog Ser 195:29-45

Zapata M, Edvardsen B, Rodríguez F, Maestro MA, Garrido JL (2001) Chlorophyll $c_{2}$ monogalactosyldiacylglyceride ester (chl $\mathrm{C}_{2}$-MGDG). A novel marker pigment for Chrysochromulina species (Haptophyta). Mar Ecol Prog Ser 219:85-98

Zapata M, Garrido JL, Jeffrey SW (in press) Chlorophyll $C$ pigments: current status. In: Grimm B, Porra RJ, Rüdiger W, Scheer U (eds) Chlorophylls and bacteriochlorophylls: biochemistry, biophysics and biological functions, Kluwer Academic Publishers, Dordrecht 